\title{
Local Solutions for Sustainable Food Systems: The Contribution of Orphan Crops and Wild Edible Species
}

\author{
Teresa Borelli ${ }^{1, *(1)}$, Danny Hunter ${ }^{1}$, Stefano Padulosi ${ }^{1}$, Nadezda Amaya ${ }^{1}$, \\ Gennifer Meldrum ${ }^{1}{ }^{\mathbb{D}}$, Daniela Moura de Oliveira Beltrame ${ }^{2}$, Gamini Samarasinghe ${ }^{3}$, \\ Victor W. Wasike ${ }^{4}$, Birgül Güner ${ }^{5}$, Ayfer Tan ${ }^{6}$, Yara Koreissi Dembélé ${ }^{7}$, Gaia Lochetti ${ }^{1}$, \\ Amadou Sidibé ${ }^{7}$ and Florence Tartanac ${ }^{8}$ \\ 1 Alliance of Bioversity International and CIAT, HQ, via dei Tre Denari 472/a, 00054 Rome, Italy; \\ D.Hunter@cgiar.org (D.H.); S.Padulosi@cgiar.org (S.P.); N.Amaya@cgiar.org (N.A.); \\ G.Meldrum@cgiar.org (G.M.); G.Lochetti@cgiar.org (G.L.) \\ 2 Biodiversity for Food and Nutrition Project, Ministry of the Environment, CEP 70068-900 Brasília-DF, Brazil; \\ dani.moura.oliveira@gmail.com \\ 3 Horticultural Crops Research and Development Institute, B365, Peradeniya 20400, Sri Lanka; \\ gaminisam@yahoo.com \\ 4 Kenya Agricultural and Livestock Research Organization, P.O. Box 57811-00200, Nairobi, Kenya; \\ victor.wasike@kalro.org \\ 5 General Directorate of Agricultural Research and Policies, Ministry of Agriculture and Forestry, \\ 06800 Ankara, Turkey; birgul.guner@tarimorman.gov.tr \\ 6 Plant Genetic Resources Department, Aegean Agricultural Research Institute, P.O. Box 9 Menemen, \\ 35661 Izmir, Turkey; ayfer_tan@yahoo.com \\ 7 Institut d'Economie Rurale, BP 438 Bamako, Mali; ykoreissidemb@gmail.com (Y.K.D.); \\ amadousidibe57@yahoo.fr (A.S.) \\ 8 Food and Agriculture Organization of the United Nations, 00153 Rome, Italy; Florence.Tartanac@fao.org \\ * Correspondence: t.borelli@cgiar.org
}

Received: 7 January 2020; Accepted: 1 February 2020; Published: 5 February 2020

\begin{abstract}
Calls for a global food system transformation and finding more sustainable ways of producing healthier, safe and nutritious food for all have spurred production approaches such as sustainable intensification and biofortification with limited consideration of the copious amounts of orphan crops, traditional varieties and wild edible species readily available in many countries, mostly in and around smallholder farmers' fields. This paper explores the potential role of locally available; affordable and climate-resilient orphan crops, traditional varieties and wild edible species to support local food system transformation. Evidence from Brazil, Kenya, Guatemala, India, Mali, Sri Lanka and Turkey is used to showcase a three-pronged approach that aims to: (i) increase evidence of the nutritional value and biocultural importance of these foods, (ii) better link research to policy to ensure these foods are considered in national food and nutrition security strategies and actions, and (iii) improve consumer awareness of the desirability of these alternative foods so that they may more easily be incorporated in diets, food systems and markets. In the seven countries, this approach has brought about positive changes around increasing community dietary diversity and increasing market opportunities for smallholder growers, as well as increased attention to biodiversity conservation.
\end{abstract}

Keywords: orphan crops; neglected and underutilized species; wild edibles; biodiversity; food composition; nutrition; policy 


\section{Introduction}

Global food production is at a critical juncture. According to the Food and Agriculture Organization of the United Nations (FAO), the world produces food in sufficient quantity to satisfy global food demand [1]; yet, in 2017, an estimated 821 million people in the world still lacked sufficient food to lead an active and healthy life [2]. Globalization, market and trade forces, as well as years of research and agricultural subsidies targeting productivity growth, have skewed crop production towards a handful of crops that can be grown to scale in the world's main breadbasket regions: India, USA, Russian Federation, China and Brazil [1]. Wheat, rice and maize now dominate global markets, contributing $51 \%$ of the world's caloric intake and underpinning global diets that are becoming increasingly homogenous [3], much like the landscapes in which they grow [4]. Market incentives to grow these crops are such that in many parts of the world farmers have replaced traditional crops with these commodities. However, these crops alone are unable to support healthy and balanced diets. Research by Krishna Bahadur KC et al. [5] comparing modern food-based dietary guidelines with agricultural production statistics highlighted that our food systems are overproducing energy-dense foods, such as sugar, grains, fats and oils, while other studies show that there is insufficient production of protein-rich food and fruits and vegetables [6,7].

Growing commodity crops in sufficient quantity to meet rising demands for food has also come at the expense of agriculture's natural resource base and wider planetary systems [8] and is threatening its future production potential. Monocultures use large quantities of external inputs, such as pesticides and fertilizers, while conversion to agriculture is the main cause of deforestation, soil erosion, greenhouse gas emission and ecosystem pollution [8]. Food production systems are also major causes of biodiversity loss-including loss of agricultural biodiversity—as the recent State of the World's report on Biodiversity for Food and Agriculture [4] and the 2019 Global Assessment Report on Biodiversity and Ecosystem Services [9] remind us. Of the different earth ecosystem components assessed in the sixth Global Environment Outlook (GEO 6) report, biodiversity health is considered the most affected by environmental degradation, with negative repercussions on the resilience of ecosystems, including agricultural systems and food security [10]. Highlighted in these reports is the rapid decline and global disappearance of many local varieties of domesticated plants and crop wild relatives, many of which are underutilized and are maintained by custodian farmers exclusively for home consumption or for informal trade [11-13]. Those species and varieties, domesticated, semi-domesticated or wild, that are being cultivated, traded and maintained mainly by farmers, and which have been marginalized by specialized modern agricultural production systems and science, are referred to in this paper as "orphan crops". Efforts to conserve and use these plant genetic resources for sustainable agriculture, food systems and sustainable and healthy diets are mostly local and poorly connected to each other $[4,14]$. They nevertheless have a tremendous potential to redress key challenges in sustainable development, viz., vulnerability of production systems to climate change, disempowerment of vulnerable groups (women and indigenous peoples), widespread poverty, shrinking food biodiversity and pervasive malnutrition [14-16].

The quest to achieve as many of the sustainable development goals (SDG) as possible by the target date of 2030 [17] and, particularly, SDG2, has prompted scientists and practitioners to think of innovative ways of increasing the supply of sufficient quantities of safe and nutritious food for current and future generations without undermining the environment. One of these ways-which is slowly gaining traction in international agendas-is to make greater and better use of the abundance and diversity of orphan crops and wild edible plant species in agriculture, food systems and supply chains while exploring creative approaches that increase consumer demand and desirability for these plant genetic resources. Starting with the Rome Declaration on Nutrition [18] and Recommendation 10 of the Framework for Action [19] adopted in 2014 during the Second International Conference on Nutrition (ICN2), which reads "Promote the diversification of crops including underutilized traditional crops, more production of fruits and vegetables, and appropriate production of animal-source products as needed, applying sustainable food production and natural resource management practices", 
increasingly more UN agencies, along with Agriculture, Nutrition and Health think tanks, acknowledge the important role biodiversity plays in supporting sustainable food systems and balanced diets. In 2016, the General Assembly of the United Nations (UNGA) proclaimed the UN Decade of Action on Nutrition (2016-2025) [20], calling upon the FAO and the World Health Organization (WHO) to lead its implementation, in collaboration with the World Food Programme (WFP), the International Fund for Agricultural Development (IFAD) and the United Nations Children's Fund (UNICEF). Specific attention to biodiversity mainstreaming for food and nutrition was accorded by several UNGA Resolutions [21], as well as by the World Health Assembly (WHA) [22], which supports policies that promote the increased use of healthy local agricultural products and foods. In 2020, the Committee on World Food Security (CFS), which sits at the science-policy interface, is set to launch the Voluntary Guidelines on Food Systems and Nutrition, which are particularly supportive of local food systems and the need to sustainably utilize cultivated and non-cultivated diversity [23].

Priority actions being advocated for making these species available to consumers include: directing increased research investments to explore their climate resilience and nutritional characteristics; providing greater support for their mainstreaming in food security policies and programs (e.g., public procurement); encouraging their use to diversify farming systems and create more biodiverse landscapes and healthier ecosystems and upgrading their value chains and markets to ensure their continued and sustainable use $[4,24,25]$.

Brazil, Kenya, Guatemala, India, Mali, Sri Lanka and Turkey are setting the pace in terms of exploring the potential role of locally available, affordable and climate-resilient orphan crops and wild edible species to support local food system transformation. With funding from the Global Environment Facility (GEF), the International Fund for Agricultural Development (IFAD) and the European Commission (EC), among other donors, Bioversity International—under its Healthy Diets from Sustainable Food Systems Initiative-has supported the seven countries in prioritizing a select range of nutritious orphan crops and wild edible species and placed them at the center of a holistic food system approach that considers both the production and consumption extremes of the food value chain. Within this initiative, the Local Agri-Foods Program sets out to deploy underused local agrobiodiversity to diversify the diets of vulnerable communities and provide a rich source of naturally available nutrients all year round. Following a brief overview of the methodology used, the paper will focus on the three-pronged approach that the countries used to: (i) increase evidence of the nutritional value and biocultural importance of these foods; (ii) better link research to policy to ensure these foods are considered in national food and nutrition security strategies and actions; and (iii) increase awareness of the desirability of these alternative food options among consumers so that they may more easily be incorporated in diets, food systems and markets (Figure 1).

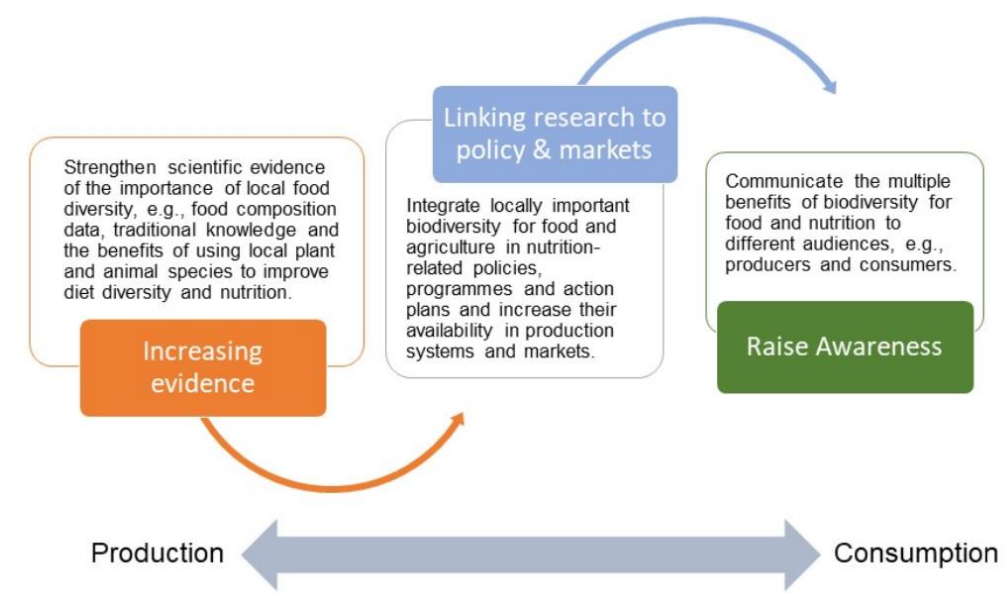

Figure 1. The three-pronged approach used by countries to establish enabling environments for mainstreaming biodiversity for food and nutrition into local food systems, from production to consumption (adapted from [26-28]). 
Although the methodology and approaches have been described in greater detail in other publications for the GEF-supported Biodiversity for Food and Nutrition (BFN) Project [26-28] and for the IFAD Project $[25,29,30]$, this is the first time the authors attempt to pull together the portfolio of work carried out by Bioversity International and its partner countries to diversify food systems using orphan crops, traditional varieties and wild edible species. Table 1 below provides an overview of the countries' focus by pillar, followed by the indicative length of implementation and budget investments. While it is understood that implementation of the approach may involve significant resources, countries with lower funding levels (e.g., Kenya) were able to successfully implement the full approach by reducing the scope of work, trimming down the number of target species and project sites and leveraging additional national and international resources for project activities.

Table 1. The table indicates the project timeframes and level of investment used by countries to implement the three-pronged approach to mainstream biodiversity for food and nutrition.

\begin{tabular}{lcccccc}
\hline & $\begin{array}{c}\text { Increasing } \\
\text { Evidence }\end{array}$ & $\begin{array}{c}\text { Linking Research } \\
\text { to Policy and } \\
\text { Markets }\end{array}$ & $\begin{array}{c}\text { Raising } \\
\text { Awareness }\end{array}$ & $\begin{array}{c}\text { Time Frame } \\
\text { (Years) }\end{array}$ & $\begin{array}{c}\text { Project Budget } \\
\text { (US\$ Million) }\end{array}$ & $\begin{array}{c}\text { Country } \\
\text { Co-Financing } \\
\text { (US\$ Million) }\end{array}$ \\
\hline Brazil & $\mathrm{X}$ & $\mathrm{X}$ & $\mathrm{X}$ & 7 & 1.72 & 59.61 \\
\hline Kenya & $\mathrm{X}$ & $\mathrm{X}$ & $\mathrm{X}$ & 7 & 0.22 & 0.24 \\
\hline Sri Lanka & $\mathrm{X}$ & $\mathrm{X}$ & $\mathrm{X}$ & 7 & 0.83 & 1.03 \\
\hline Turkey & $\mathrm{X}$ & $\mathrm{X}$ & $\mathrm{X}$ & 7 & 1.04 & 2.26 \\
\hline India & $\mathrm{X}$ & $\mathrm{X}$ & $\mathrm{X}$ & 5 & 0.90 & 0.40 \\
\hline Guatemala & $\mathrm{X}$ & $\mathrm{X}$ & $\mathrm{X}$ & 5 & 0.33 & $0.13 *$ \\
\hline Mali & $\mathrm{X}$ & & $\mathrm{X}$ & 5 & 0.36 & $0.13 *$ \\
\hline
\end{tabular}

Over several years, the countries have generated scientific evidence of the nutritional value of 188 orphan crops and wild edibles species and achieved positive changes around improving community dietary diversity, increasing market opportunities for smallholder growers and gaining increased attention for biodiversity conservation and climate-smart agricultural practices. The paper concludes by identifying global opportunities to create momentum around the conservation and use of orphan crops and wild edible species for sustainable agriculture, diversified food systems and sustainable and healthy diets.

\section{Background}

The extraordinary diversity of ecosystems and food species that Brazil, Kenya, Guatemala, India, Sri Lanka and Turkey support made these countries ideal candidates for the interventions established under the different funding mechanisms outlined above. With the exception of Mali (Mali was chosen in response to a specific request made by IFAD to support one of its agricultural investment programs operating in the country, focusing on enhancing and leveraging local agrobiodiversity to support nutrition, climate change and income outcomes), the six other countries are among the highest in terms of species richness and endemism. Despite this natural abundance, they suffer alarming rates of one or more forms of malnutrition (Table 2). At the same time, the native edible biodiversity that they harbor, both wild and cultivated, is threatened by environmental pressures or lack of use. 
Table 2. The table shows the countries' respective ranking according to the Convention on Biological Diversity's (CBD's) Biodiversity Index and the Global Hunger Index. It also captures the multidimensional nature of hunger, where overweight and stunting often occur in the same population, despite the high levels of biodiversity.

\begin{tabular}{|c|c|c|c|c|c|}
\hline \multirow[t]{2}{*}{ Country } & \multirow{2}{*}{$\begin{array}{l}\text { Biodiversity } \\
\text { Index Rank * }\end{array}$} & \multirow{2}{*}{$\begin{array}{l}\text { Global Hunger } \\
\text { Index Rank ** }\end{array}$} & \multicolumn{3}{|c|}{ Malnutrition *** } \\
\hline & & & $\begin{array}{c}\text { Prevalence of } \\
\text { Overweight (in } \\
\text { Women }+18 \text { Years) }\end{array}$ & $\begin{array}{c}\text { Prevalence of } \\
\text { Anemia in Women } \\
\text { (15-49 Years) }\end{array}$ & $\begin{array}{c}\text { Prevalence of } \\
\text { Stunting (Children } \\
<5 \text { Years) }\end{array}$ \\
\hline Brazil & 4 & 18 & $55.4 \%$ & $27.2 \%$ & $7 \%$ \\
\hline Guatemala & 17 & 72 & $59.9 \%$ & $16.4 \%$ & $46.7 \%$ \\
\hline India & 18 & 102 & $21.6 \%$ & $51.4 \%$ & $37.9 \%$ \\
\hline Kenya & 44 & 86 & $34.3 \%$ & $27.2 \%$ & $26.2 \%$ \\
\hline Mali & 140 & 83 & $35.1 \%$ & $51.3 \%$ & $30.4 \%$ \\
\hline Sri Lanka & 36 & 66 & $27.4 \%$ & $32.6 \%$ & $17.3 \%$ \\
\hline Turkey & 70 & $1-17$ & $69.3 \%$ & $30.9 \%$ & $9.9 \%$ \\
\hline
\end{tabular}

* NBI-The National Biodiversity Index of the Convention on Biological Diversity is based on estimates of country richness and endemism in four terrestrial vertebrate classes and vascular plants. Vertebrates and plants are ranked equally. Index values range between 1.000 (maximum: Indonesia) and 0.000 (minimum: Greenland). The NBI includes adjustments allowing for country size. The values shown are expressed over 161 countries. Countries with land area less than $5000 \mathrm{~km}^{2}$ are excluded [31]. ${ }^{* *} 2019$ Global Hunger Index. Based on 117 countries ranked on a 100 -point GHI Severity Scale, where 0 is the best score (no hunger) and 100 is the worst [32]. ${ }^{* *}$ Global Nutrition Report country nutrition profiles [33].

Brazil, for example, is one of the 17 most diverse countries in the world, hosting between $15 \%-20 \%$ of the world's biological diversity, with the greatest number of endemic species on a global scale [34,35]; yet, micronutrient deficiencies are prevalent, with $27.2 \%$ of women of reproductive age suffering from anemia and $54 \%$ of the adult population overweight [36].

At the other end of the spectrum, Mali carries the so-called "triple burden of malnutrition", in which hunger, overweight and micronutrient deficiencies coexist in the same population and often in the same individual across the life cycle. In 2015, 26\% of children and adolescents in Mali were underweight, while an average $27.7 \%$ of adults were overweight and $51.3 \%$ of women of reproductive age suffered from anemia [37]. Although the abundance of agricultural biodiversity in the West African countries is significantly lower than Brazil, a number of nutrient-rich seasonal green leaves, semi-domesticated crops and wild foods—such as baobab leaves (Adansonia digitata), African locust beans (Parkia biglobosa), jute mallow (Corchorus olitorius) and amaranth (Amaranth sp.)—could potentially increase dietary quality, particularly in rural and resource-poor areas [38,39].

One of the immediate causes of malnutrition is either lack of food or the excessive consumption of calorie-dense, heavily processed foods and/or the insufficient consumption of key foods such as nutritious fruits, vegetables, nuts and seeds [40]. In the Sikasso region of Mali, rice, millet and sorghum constitute the bulk of the daily diet, with vegetables consumed in small quantities as a side dish [41]. Reportedly, less than $200 \mathrm{~g}$ of vegetables per day per person are consumed, well below the recommended $400 \mathrm{~g} /$ day recommended by the World Health Organization [37]. At the same time, a study by Siegel et al. [6] highlighted that the global and national fruit and vegetable supply is insufficient to meet the nutritional needs of current and growing populations, urging the global nutrition and agricultural communities, particularly in low-income countries, to find innovative ways of increasing fruit and vegetable production and consumption to meet population health needs.

One approach, which the seven countries embraced, is to better harness local agricultural biodiversity, including orphan crops and wild species, which are equally or often nutritionally superior to exotic crops [26,42,43], as well as being more resistant to biotic and abiotic stresses [44]. However, a number of barriers exist to the successful integration of orphan crops and wild edible species in food systems. These can be summarized as: (i) limited and fragmented data available on their nutritional value and potential benefits; (ii) limited capacity (technical, structural and financial) and research partnerships to fill this knowledge gap and generate more evidence; (iii) disabling policies and regulatory frameworks that fail to encourage the greater production and consumption of food 
biodiversity; (iv) unfavorable trade policies and poorly developed markets and infrastructure; (v) low consumer awareness and negative perceptions associated with their consumption and (vi) limited awareness and understanding of the nutrition, environmental and economic benefits that could arise by mainstreaming biodiversity for food and nutrition [45-47]. The sections below provide some insights on how these barriers were tackled through multi-stakeholder collaborative efforts realized by Bioversity International and its partners in Central America, Africa and South Asia over the last few years. As explained in greater detail in Section 3.2, although not easy to establish, multi-stakeholder policy platforms can make use of pre-existing frameworks, such as the ones established in Brazil under the Zero Hunger program [48], or be created from scratch, building on the momentum of national and international efforts to tackle malnutrition or biodiversity conservation, to develop biodiversity-sensitive school-feeding policies/programs [49] or a nutrition-sensitive biodiversity conservation plan (e.g., the Busia County Biodiversity Policy [50]).

\section{Materials and Methods}

\subsection{Assessing Available Food Diversity}

Trimming down the large amount of edible biodiversity that is present in each of the countries to a manageable sample size required an initial understanding of the breadth of this diversity, as well as national consensus on the desirable traits for selection. In the case of the BFN, in the project's preparatory phase, countries had undertaken a set of background studies and literature reviews revealing that information was present but mostly scattered across information sources and incomplete [28]. Only for Brazil had attempts been made to prioritize existing biodiversity for food and nutrition under the Plants for the Future (PFF) initiative spearheaded by the Ministry of the Environment. PFF had singled out 674 species of potential economic value across its five ecoregions (i.e., South, South-East, Central, North and North-East), of which 41 were edible. Kenya, Sri Lanka and Turkey had to carry out extensive literature reviews, ethnobotanical assessments and focus group discussions with key informants, as well as convening national experts, to prioritize the most appropriate species to include in the interventions [28].

Surveys were also used to capture traditional knowledge related to the species, as well as local names; habitats; parts used; specific uses (fruit, vegetable, staple, etc.) and users (by gender); seasonality; preparation and conservation and availability. Traditional knowledge, which is recognized by SDG Target 2.5 as underpinning the conservation and management of biodiversity and local and indigenous food production systems [14], is itself threatened by the loss of traditional lifestyles and food cultures, following rapid urbanization and the industrialization of agriculture and food processing [4]. In Turkey, market surveys targeting local plant collectors, sellers and consumers in three different ecogeographic regions helped gather information on 43 wild edible species, including mushrooms and landraces [26,28], while interviews with quilombola communities living in the Central-West and North-East regions of Brazil helped document traditional knowledge on the use of 16 native fruit species, such as the native dwarf cashew (Anacardium humile), which is eaten as a fruit, as well as a nut, by local communities. The continued cultivation of orphan crops, such as different cowpea varieties (Vigna unguiculata), in Turkey continues mostly thanks to women who use these ingredients in traditional dishes [28].

In Mali and Guatemala, seasonal agrobiodiversity assessments and consultations with local communities focused on existing food plant diversity (wild and cultivated), related uses and the assessment of climate resilience traits, as perceived by farmers. These investigations revealed a large diversity of cereals, legumes, fruits and vegetables that could be better leveraged to increase dietary quality and diversity while contributing to a greater climate adaptation of local production systems [39,51]. Turkey, whose focus was on wild edible plants, went one step further and developed a prioritization matrix that considered issues of environmental, economic and market sustainability to rank the species [28]. Of relevance to the environmental sustainability ranking was the existence of 
national domestication programs targeting the species. This is especially important when dealing with the increased commercialization of wild plants or fruits to ensure the plants are not overexploited and their growing habitats maintained. Although lengthy to set up, domestication programs ensure that farmers have access to good quality seed and can grow the species easily in their fields while reducing collection pressure on the wild populations. Many such programs are likely already taking place at the national level, as was the case for the golden thistle (Scolymus hispanicus) in Turkey and for African indigenous vegetables in Kenya. As interest for these forgotten resources grows, there may be a need to expand the programs to increase seed production, accompanied by sustainable collection guidelines where domestication programs cannot be set up.

\subsection{Assessing the Quality of Diversity}

Within the BFN Project [52], Brazil, Kenya, Sri Lanka and Turkey worked through national universities and research institutes to determine the nutrient composition of 188 orphan crops and wild edible species using methodologies developed by the FAO/INFOODS [53] while engaging with local communities to document traditional knowledge associated with these crops. For example, spearheaded by the Ministry of the Environment, Brazilian federal universities and research institutes compiled and generated food composition data for 70 native fruit species, many of which are wild-harvested, demonstrating their nutritional advantage over more commonly consumed exotic fruits. In Kenya, the Kenya Agricultural and Livestock Research Organization, working in partnership with the Ministry of Health and FAO, generated nutritional data on a select number of orphan crops and semi-domesticated species that are traditionally grown in home gardens or by family farmers. A full list of research partners and institutes is provided in Hunter et al. [26].

\section{A holistic Approach to Diversifying Diets and Markets for Orphan Crops}

\subsection{Increasing Evidence of the Value of Orphan Crops}

Evidence is the first necessary step to transform the enabling environment for biodiversity to improve nutrition (Figure 1) [47]. It is one of the three main pillars that underpin implementation of the FAO Voluntary Guidelines for Mainstreaming Biodiversity into Policies, Programmes and National and Regional Plans of Action on Nutrition, which aim at "addressing malnutrition in all its forms and, specifically, to promote knowledge, conservation, development and use of varieties, cultivars and breeds of plants and animals used as food, as well as wild, neglected and underutilized species contributing to health and nutrition" [54]. Stronger evidence of the nutritional value of biodiversity is also considered by thought leaders as one of the main areas for aid investment with the greatest untapped potential to support the reduction of undernutrition and increase dietary diversity, particularly among the poorest, who depend most on the sustainable use of natural resources [55]. However, limited information exists on the nutritional value of orphan crops and of the traditional knowledge associated with their collection, preparation and use. It is estimated that global databases, such as the International Network of Food Data Systems hosted by the FAO (FAO/INFOODS Food Composition Database for Biodiversity) [56] and Food Composition Tables (FCTs), capture a meager 1\% of the nutritional information of foods consumed globally, let alone foods derived from local biodiversity [57]. Of the 10,156 foods recorded in the FAO/INFOODS database, only a modest $3118(31 \%)$ are identified as wild plant and animal foods (belonging to a total of 1289 species). Of these, $1 \%$ are legumes, $4 \%$ nuts and seeds, $12 \%$ are starchy roots and tubers and $11 \%$ are vegetables [4]. In most cases, data are available for macronutrients and minerals, whereas vitamin and phytochemical compositions, which are particularly relevant to the promotion of wild and biodiverse foods, are seldom provided [4]. Food composition analysis carried out in Brazil as part of the BFN work confirmed that native species such as camu-camu (Myrciaria dubia), guabiroba (Campomanesia xanthocarpa), mangaba (Hancornia speciosa) and cagaita (Eugenia dysenterica) contain significantly higher levels of vitamin C compared to oranges, limes and tangerines [26], while 
the native fruits buriti (Mauritia flexuosa), tucumã (Astrocaryum aculeatum) and pitanga (Eugenia uniflora) are richer in provitamin A carotenoids than more commonly available and consumed fruits (Figure 2).

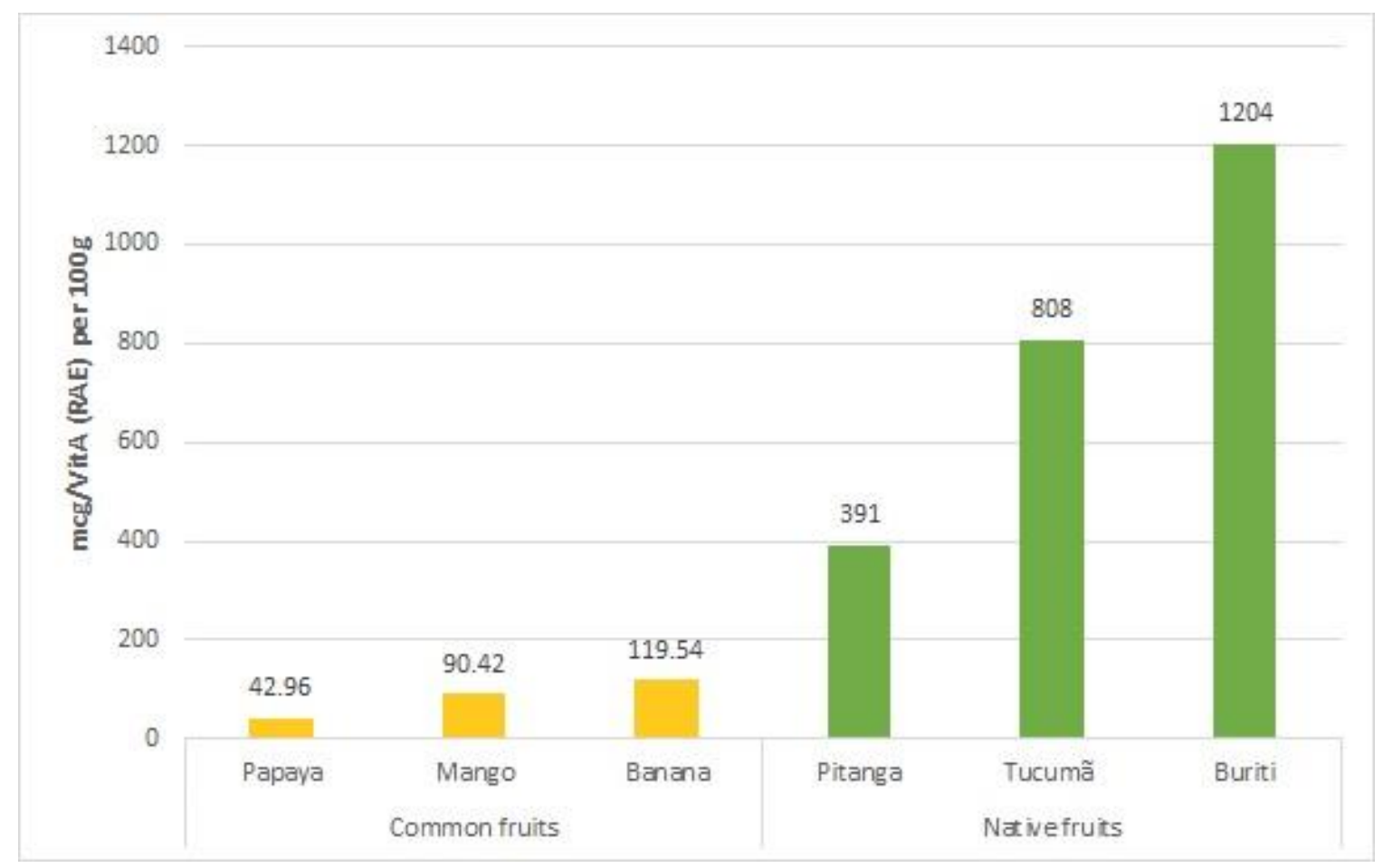

Figure 2. Vitamin A content (expressed in mcg RAE per 100g of fresh raw pulp/whole fruit, with or without peel) of the native Brazilian fruits pitanga (Eugenia uniflora), tucumã (Astrocaryum aculeatum) and buriti (Mauritia flexuosa) compared to more commonly available vitamin A-rich fruits. Source: Brazilian food composition tables [58] and the System on Brazilian Biodiversity (SiBBr) database [59].

Similar results were obtained in Kenya. In the case of African leafy vegetables, results showed that, compared to cabbage (Brassica oleracea), amaranth (Amaranthus dubius) contained almost 3.5 times as much beta-carotene equivalent - the primary plant-based source of dietary vitamin A- while Malabar spinach (Basella alba) contained 13.5 times as much iron [26]. In the same study, investigations into the nutrient content of different Sri Lankan rice varieties (Oryza sativa), comparisons of finger millet varieties (Eleusine coracana) across geographic locations and the nutritional analysis of wild edible plants in Turkey confirmed the high levels of intra- and inter-species diversity that have previously been reported in literature [60,61]. Table 3 provides a summary of the micronutrient content (important minerals and vitamins) of target underutilized species generated by food composition analyses in three of the four BFN countries. These results further highlight the importance of including a wide range of species and varieties in diets to improve diet quality [62]. 
Table 3. The table summarizes the micronutrient content of select underutilized fruits, vegetables and cereals obtained via food composition analyses in Brazil, Kenya and Sri Lanka. Values are expressed per 100g of raw parts used. Source: Biodiversity for Food and Nutrition (BFN) Species Database [63]

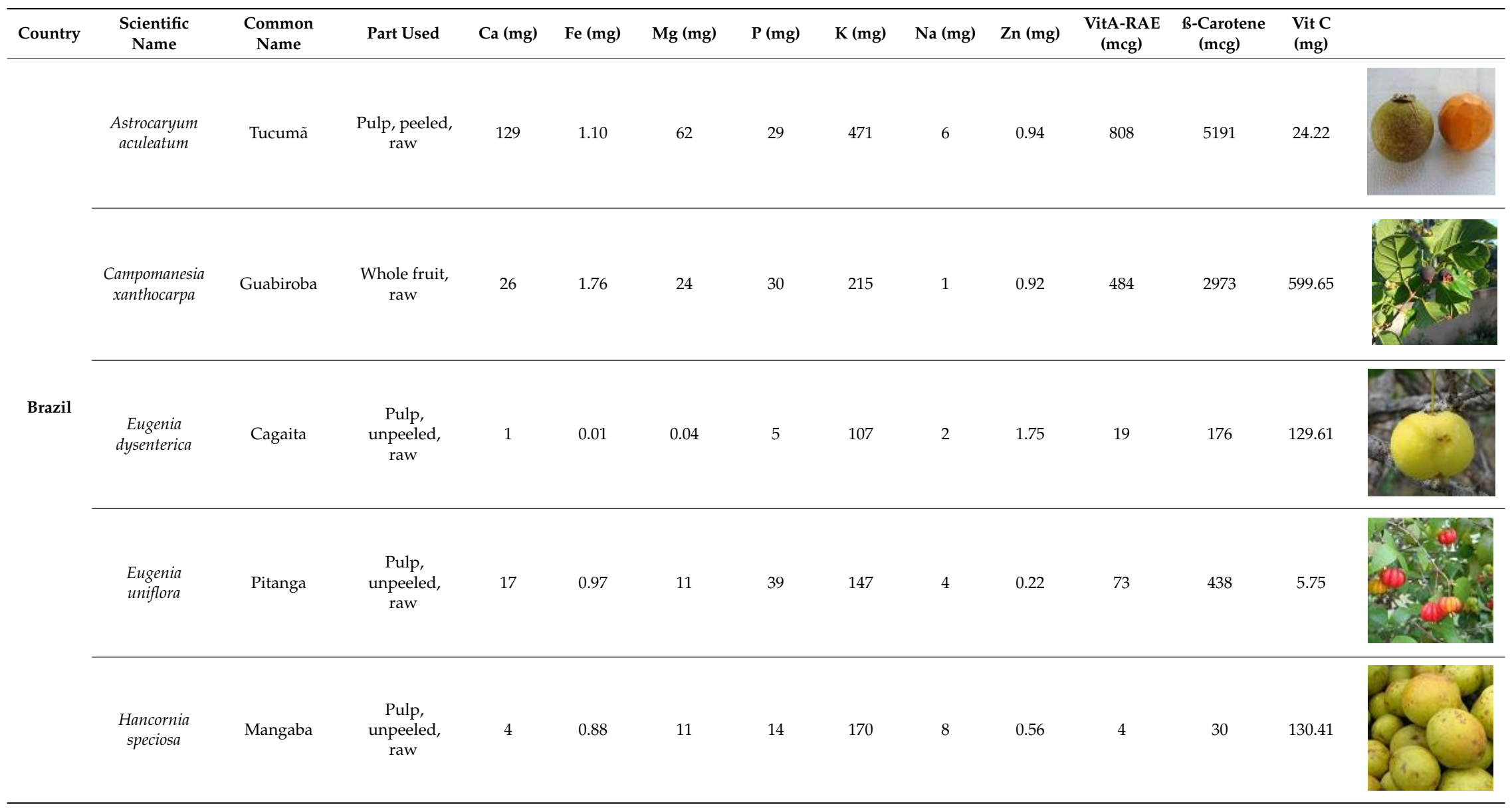


Table 3. Cont

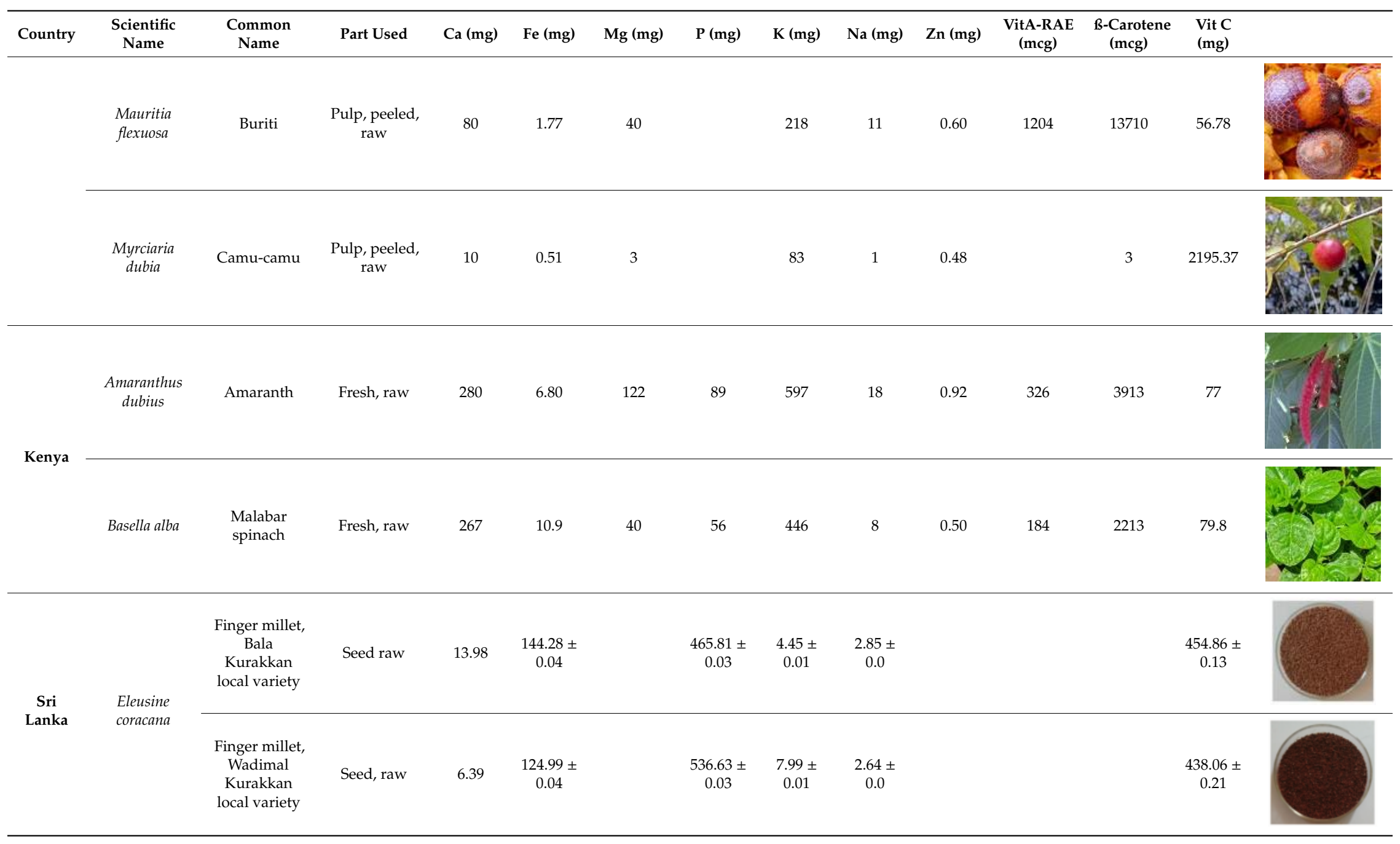


Collectively, the countries have made the single largest contribution to the FAO/INFOODS database and to broadening global knowledge of the nutritional value of orphan crops and wild edible species for potential integration into national and global food systems. The leafy vegetable chaya (Cnidoscolus aconitifolius), an evergreen, hardy shrub that was domesticated by the Mesoamericans in pre-Columbian times and is typically cultivated on a small scale in gardens and field margins for household use [64], contains high amounts of several macro- and micronutrients, including protein (60g per $1 \mathrm{~kg}$ of leaves), vitamin A, niacin and vitamin C [65]. In Mali, the cereal fonio (Digitaria exilis) is rich in the amino acids methionine and cysteine [66], while Bambara groundnut (Vigna subterranea), with its chemical composition comparable to soy bean, is a good source of quality protein, fat and carbohydrates-enough to be considered a complete food $[67,68]$. Short growth cycles (for fonio) and the ability to grow well in resource-poor settings with limited water and minimal external inputs, make these crops particularly suited for growing in harsh environments, providing important contributions to food security, especially in times of food scarcity and extreme climate conditions [69]. Despite their importance, fonio and Bambara groundnut are presently cultivated only at a small scale and have been displaced by other crops that are better supported by the extension and marketing systems [70-72]. Through complementary investigations on markets and value chains of these climate-smart crops, farmers and other stakeholders also gained a better understanding of bottlenecks hindering the wider use of these local crops and acted to address these through multiple measures, as done effectively in the case of chaya in Guatemala [73].

\subsection{Linking Research to Policy and Markets}

Once obtained, reliable nutritional data on orphan crops and other nutritious biodiversity can be used as evidence to inform and shape global and national policies that currently incentivize the production of cheap, unhealthy food with a large environmental footprint, while minimizing diversity on farms and in agricultural landscapes [74,75]. This evidence has been recognized as crucial in the creation of enabling environments that are more conducive to enhancing nutrition and are aimed at making healthy, diversified and sustainable foods available to all and the easy default choice in local and global food markets [47].

The process, referred to as "biodiversity mainstreaming", indicates the "integration of actions that conserve and sustainably use biodiversity into strategies for production sectors such as agriculture, fisheries, and forestry" [27]. The approach can either be centralized (top-down), using country participation in international agreements to align national agendas with international priorities, or bottom-up, using a decentralized approach to guide national policies towards increasing the amount of attention, funding, technical and service support for orphan crops to make food systems more nutritious, while supporting sustainable agricultural practices and links with smallholder farmers. Both approaches would ideally be needed for the mainstreaming process to be effective and meaningful across key sectors of society (viz., agriculture, environment, nutrition, health, trade and education) and economically viable to farmers and all the other value chain actors, including consumers.

The Convention on Biological Diversity (CBD) and its Strategic Plan for Biodiversity 2011-2020 [76] offers a useful platform to mainstream the conservation and sustainable use of biodiversity for improved nutrition. The CBD has near-universal participation among countries and explicitly recognizes the potential of orphan crops and wild edibles to contribute to food systems' transformations and improve human health [77]. Sri Lanka is one of the 196 countries that are party to the CBD. It used evidence generated under the BFN Project on the nutritional importance of 28 traditional edible plant species and 58 varieties-including traditional rice varieties, cereals, pulses, root and tuber crops and vegetables-to update and revise its National Biodiversity Strategy and Action Plan (NBSAP) and better align its national targets with the global targets established by the Strategic Plan for Biodiversity-the so-called Aichi Biodiversity Targets (a set of 20 time-bound global targets under the Strategic Plan for Biodiversity 2011-2020) [76]. Data was used to justify and better integrate biodiversity concerns and nutrition-related objectives into NBSAP targets, so that National Target 2 now reads "Promote and 
mainstream underutilized, lesser-known or neglected food crops, livestock and food fishes, which provide nutrition" [78]. Strategic partnerships with multisectoral, key-line ministries established under the BFN Project led to similar results in Brazil, where Strategic Objectives and Targets of the most recent NBSAP [79] explicitly recognizes the nutritional value of native biodiversity (including orphan crops and wild edibles) and employs greater information and utilization of native nutrient-rich plant species as a successful measure of biodiversity conservation. The conservation of biodiversity for food and nutrition was included as a priority action for Target 13 (Conserve the gene pool) but recognized as having manifold benefits that directly impact Biodiversity Targets 1 (Understand values), 2 (Mainstream biodiversity), 3 (Address incentives), 4 (Sustainable production), 7 (Manage within limits), 14 (Restore ecosystems) and 18 (Respect and conserve traditional knowledge). Furthermore, many targets and/or initiatives targeting the conservation and sustainable use of native biodiversity were used to guide Brazil's Multi-Year Budget Plan (2016-2019). The continued integration of biodiversity research into national policies has helped establish long-term support for biodiversity as a link between agriculture and nutrition, translating into increased research funding for the nutritional profiling of orphan crops, incentives to grow these crops using agroecological practices and encouraging the diversification of the food supply by increasing their availability in markets.

One of the main policy instruments that has greatly enhanced market recognition for orphan crops and wild edibles using evidence generated by the BFN is Ordinance 284 (that supersedes ordinance 163/2016) on "Brazilian Sociobiodiversity Native Food Species of Nutritional Value", which identifies 101 marketable species, mostly wild edible fruits and nuts, and recognizes their key role for food and nutrition security [80]. The ordinance, jointly developed by the Ministries of Environment and Social Development, increases farmer incentives to continue growing and managing the species, which can be sold via two important public procurement programs: the National School Feeding Program (PNAE), which establishes that at least $30 \%$ of the food purchased with federal funds must be procured directly from family farmers, and the Food Acquisition Program (PAA), which pays an additional $30 \%$ for organic and agroecological produce grown by family farmers [81]. Complementary to PAA, the Minimum Price Guarantee Policy for Sociobiodiversity Products (PGPM-Bio) reduces farmer vulnerability to price volatility in food markets and steps in to compensate producers when their sociobiodiversity products do not attain the market value established by the National Supply Company [82]. Since the ordinance was launched in 2016, purchases for sociobiodiversity species by the PAA doubled from US \$1M in 2014 to US \$2.5M in 2016, while, between 2018 and 2019, minimum guarantee prices for wild edible fruits managed by extractivist communities have increased by $11.21 \%$ for buriti (Mauritia flexuosa) and $19.07 \%$ for juçara (Euterpe edulis) [83]. A structured demand for agrobiodiversity has been shown to engender other positive downstream effects, such as on farm diversification, improved management practices, increased land size devoted to horticultural production and increased availability of nutritious foods in local food systems [84]. However, the percentage of funds used by the PNAE and PAA to purchase native biodiversity products remains low (2\%) relative to mainstream commodity crops [81].

In Kenya, where multisectoral platforms that tackle food security and nutrition issues are still emerging, and where the revised Constitution (2010) has devolved environmental management functions to the counties, a decentralized, bottom-up approach was used to mainstream biodiversity and nutrition-related concerns into the drafting of new policy documents and guidelines. Food composition data for traditional leafy greens such as malabar spinach (Basella alba), jute mallow (Chorchorus olitorius), spider plant (Cleome gynandra) and amaranth (Amaranthus dubius), as well as continuous engagement by the national BFN team with local policymakers, farmer groups, communities and schools, helped raise awareness of the value of traditional orphan crops and other nutrient-rich species and support the formulation and endorsement of a County Biodiversity Policy that recognizes the role of biodiversity in food security and nutrition, as well as livelihood and ecosystem resilience. The policy has also allocated resources to build the capacity of small-scale farmers to produce greater diversity and to conserve and promote regional biodiversity for food and nutrition, with specific 
provisions for designated conservation areas and the incorporation of biodiversity concerns into school curricula and nutrition education programs. First of its kind for any of Kenya's 47 counties, the policy has the potential to cause a ripple effect and positively influence neighboring counties and national policy-making. The policy is all the more important because it recognizes the need for greater investments in building farmer capacity to increase productivity of local biodiversity, to be able to apply food safety and quality standards and to access technology and markets that currently favor large-scale producers. At present, limited space exists for orphan crops and wild edibles in formal global food systems/markets, which apply rigorous quality standards that focus on product uniformity; limit production variability $[85,86]$ and fail to recognize the social, cultural, economic and ecological benefits that diversified production systems engender. Demand for staple crops are common, while tenders for orphan crops, such as the broad range of African leafy vegetables (ALVs), are nonexistent. Even when market opportunities exist, smallholder farmers lack the capacity to pursue them. Few can write a business plan or a loan application to a local microfinance institution or a commercial bank. This means that smallholder farmers lack access to a steady market for orphan crops and are excluded from value addition opportunities that could generate extra income.

The seven countries have tried to fix some of the broken linkages along the value chain by creating a strong market for these crops, as well as exploring alternative, secondary markets. Model gardens and demonstration plots established in Aranayaka, Sri Lanka by the Department of Agriculture, in collaboration with the Community Development Centre (NGO), for example, have overseen the creation of a value chain (from production to consumption) for 36 traditional wild edible yams and tuber varieties belonging to the genus Alocasia, Dioscorea and Colocasia. Demonstration plots established in 18 villages provide training on sustainable land management practices, integrated pest management and the cultivation of these orphan crops. At the same time, training is provided on value addition and the creation of novel food products that are then marketed in agrobiodiversity outlets across Sri Lanka. The pilot is currently reaching 2000 individuals in Aranayaka, while around 100 families have directly engaged in the marketing of products made from traditional roots and tubers, reaching monthly profits of US $\$ 42$ per family.

Public procurement policies also offer strategic entry points for the greater mainstreaming of agricultural biodiversity, offering a structured demand for this diversity and generating multiple benefits across all the elements of sustainability: economic, social and environmental $[87,88]$. In India, through the IFAD NUS Project [89]. Bioversity International and the M.S. Swaminathan Research Foundation (MSSRF) worked closely to provide scientific and development evidence of the comparative advantage of using minor millets rather than mainstream crops in the country's Public Distribution System (PDS) [90]. In 2013, sustained lobbying efforts led to the approval by Parliament of the National Food Security Act [91], which conceded the inclusion of a diverse range of food grains in the national food distribution schemes. These previously neglected grains include finger millet (Eleusine coracana), foxtail millet (Setaria italica), proso millet (Panicum miliaceum), kodo millet (Paspalum scrobiculatum), little millet (Panicum sumatrense) and barnyard millet (Echinochloa colona). The passing of this law represents an historical milestone in the pathway towards a more resilient and nutritious food system in India, a country which, until 2013, had been sourcing only wheat and rice for its food distribution schemes. Increased production of these highly resilient and nutritious cereals is also expected to enhance India's capacity to adapt to climate change and counteract food insecurity, especially in the more marginal areas where millets perform better than rice and wheat in terms of nutritional yields [92]. Other social benefits stemming from this supportive environment are foreseen in terms of biodiversity conservation, empowerment of women and maintenance of India's unique food traditions and cultural identity, which minor millets are an important part of $[29,93]$.

Similarly, in Guatemala, collaboration with the Ministry of Education, the Ministry of Public Health and Social Assistance, the Ministry of Agriculture and local nongovernmental organizations (NGOs) is leading to the greater use of orphan crops in the country's school meal programs. The recently approved National School Feeding Law (Ley de Alimentación Escolar-Decree no. 16-2017) establishes 
that schoolchildren aged 6 to 12 are provided with culturally-relevant, healthy and nutritious meals that fulfill $25 \%-35 \%$ of a child's daily energy and protein requirements, and that includes all food groups (carbohydrates, proteins, fruits, vegetables and fat). It also emphasizes procuring fresh foods within the vicinity of the school, preferably from local producers who practice family farming. Using agronomic and nutritional data, Bioversity International, in partnership with the NGO Mancomunidad Copanch'orti', was able to promote the use of chaya (Cnidoscolus aconitifolius) in the school meals program of the Department of Chiquimula. Chaya's nutritional and drought-tolerant properties, accompanied by ease of production, affordability, acceptability and availability, ensured its inclusion as a key ingredient in two of the 20 dishes that composed Chiquimula's official school meal menu in 2019 , benefiting more than 80,500 students. Chaya is also being considered as an alternative ingredient in four other dishes, to be used with other leafy vegetables, such as chipilín (Crotalaria longirostrata) and black nightshades (Solanum americanum and Solanum nigrescens), when suitable. Central to the greater use of chaya was the preparation of a recipe book that proposes new, creative and likeable recipes using chaya. Prepared in collaboration with local communities, the recipe book considers local practices and culinary specificities that are pleasing to local tastes. The recipes are easy-to-follow and incorporate colorful pictures while considering children's preferences and include foods like chaya popsicles, porridge and rice pudding. While schools can function as institutional markets for the procurement of orphan crops, as seen in Guatemala, or in the case of African leafy vegetables and other nonconventional vegetables and native fruits [82], they are also an important platform to improve nutrition through education and behavioral changes, as demonstrated in the next section.

\subsection{Raising Awareness: The Power of Evidence to Drive Change}

Information or guidance currently abound on how to change our food systems so that they nourish humanity in a healthy manner, do not harm the environment, reduce public health impacts and are equitable and just [94]. The EAT-Lancet Commission Report [95] and World Resources Report [96] are the latest, but there are many reports that suggest key opportunities and recommendations that can inform productive action. They also acknowledge that food systems and environments are not only driven by trade policies and the food industry but are equally underpinned by consumer demand, where consumers can drive supply via their food choices [8]. For a healthy food system transformation to occur [94], consumers need to be aware of the benefits of diversifying their diets and the impact of their food choices, not only on their own health and well-being, but also on the food system and the environment. The reality, however, is that most consumers are inadequately informed about what constitutes a balanced diet; they do not necessarily prioritize nutrition and health when choosing food, and they lack the capacity and resources to utilize the diversity that is available or tend to prefer convenience food that is often more easily available and accessible in today's food environments [85]. Furthermore, the relevance of biodiversity for food and nutrition may not be apparent to most consumers and is often an underappreciated and overlooked resource. In many cultures, the consumption of orphan crops and wild species occurs in times of food deprivation or illness - as many of the species have medicinal properties—thus evoking negative experiences and perceptions, as well as unfair labeling such as food "for the poor" or "food for the sick". However, in other parts of the world, orphan crops and wild edibles continue to be used in cultural and religious festivals $[4,43]$ or in traditional cuisine and gastronomy. The seven countries in this paper used these positive connections to biocultural heritage as an entry point for increased appreciation and support for orphan crops and wild edible species, using unique, context-specific approaches to creating awareness. Nutritional data for these species and information about their occurrence across seasons and their uses and benefits can be included in educational activities and materials used by extension services as well as awareness campaigns encouraging consumers to make informed choices [27].

Nutrition education is the main conduit to support the adoption of food choices and other food-and-nutrition-related behaviors conducive to health and well-being in both youths and adults. Working with relevant government institutions, entry points can be identified for the inclusion of 
messaging around the importance of consuming varied diets and favoring local foods, as well as the importance of sustainable production practices. A useful tool for the greater appreciation of orphan crops is the use of school gardens. In Brazil, the BFN worked closely with the "Educating with School Gardens and Gastronomy" Project (PEHEG) implemented by the Ministry of Education and the University of Brasília to help children reconnect with their food system while promoting the inclusion of nonconventional vegetables and native fruit tree nurseries in schools. School gardens in Kenya were set up to complement school meal programs [97] but also doubled-up as educational tools with the potential to incorporate lessons from different disciplines, such as mathematics, biology, geography, agriculture and economics, into gardening activities. Similarly, in Turkey, school gardens [98] and nature walks were used to heighten the appreciation of traditional foods and wild edible species among gastronomy students of a vocational training college, contributing to "greening" and broadening their culinary horizons and accessing better job opportunities.

To further support the adoption of healthier food choices, countries such as Brazil have produced national public health resources that highlight the need for dietary diversification to meet essential nutritional needs. The Brazilian food-based dietary guidelines [99], for example, approach food consumption from a completely original perspective, promoting the consumption of a variety of whole foods rather than discussing separate nutrients and calories. The guidelines are used to guide government actions linked to the food and nutrition agenda-including patient care by doctors and nutritionists, school meals, nutrition education and food labeling. They focus on homemade, nutritious meals and encourage citizens to become more mindful of the social, emotional, cultural and political meaning of food and be critical of ultra-processed foods. They also include advice on cooking culturally important dishes; create appreciation for regional foods and traditional dietary habits and highlight the links between healthy eating patterns; the promotion of biodiversity; shorter value chains and physical, social and environmental health. Unsurprisingly, the adoption of healthier food choices will not happen overnight, but monitoring and evaluation exercises, such as household/population surveys, can be set up at the onset and at the end of the intervention to assess increased consumption of orphan crops. If possible, and in the case of long-term interventions, linkages can be sought with the agencies responsible for social and demographic surveys.

Seasonal availability calendars were developed using participatory community assessments in Guatemala, Mali and India to encourage the year-round consumption of locally available and diverse fruits and vegetables. The species available per month were recorded and identified using local names and easily recognizable pictures. The calendars and information booklets distributed to communities following these assessments included information on national food-based dietary guidelines, as well as results of local diet surveys that generally revealed low levels of fruit and vegetable intakes. As shown in Figure 3, fruits and vegetables were divided into food groups from the Minimum Dietary Diversity for Women indicator [100]—dark, green, leafy vegetables, vitamin A-rich fruits and vegetables, other fruits and other vegetables-and information was provided on the unique nutritional role of each group. Simple recommendations were included on how to improve diet quality using the seasonal calendar, including planning the home garden to ensure year-round availability of fruits and vegetables, adding seasonally available produce to recipes to give a touch of color and encouraging families to eat fruits and vegetables on a daily basis.

Food innovations and gastronomy are also playing an increasingly important role in reversing the negative perceptions associated with many nutritious orphan crops. In Mali, nutritionists and food technologists at the Institut d'Economie Rurale (IER) developed new culturally acceptable recipes and novel food products using fonio, Bambara groundnut, jute mallow and amaranth (Table 4). These foods were analyzed for their nutrient contents (e.g., energy, protein, carbohydrate, fat, fiber, iron and zinc); underwent sensory evaluation tests and were promoted within communities and at diversity fairs organized in the Ségou and Sikasso regions (Figure 4). Likewise, in Guatemala, local women were trained on a protein extraction process for chaya leaves. The protein can then be used to enrich traditional foods, such as tamales (steamed maize dough wrapped in maize husk), 
tortillas (thin flatbread made from ground maize cooked in limewater), lemonade and scrambled eggs. Follow-up actions with the communities who grow and maintain these crops included cooking and value addition training sessions with a focus on quality and food safety standards in processing, preservation and packaging.

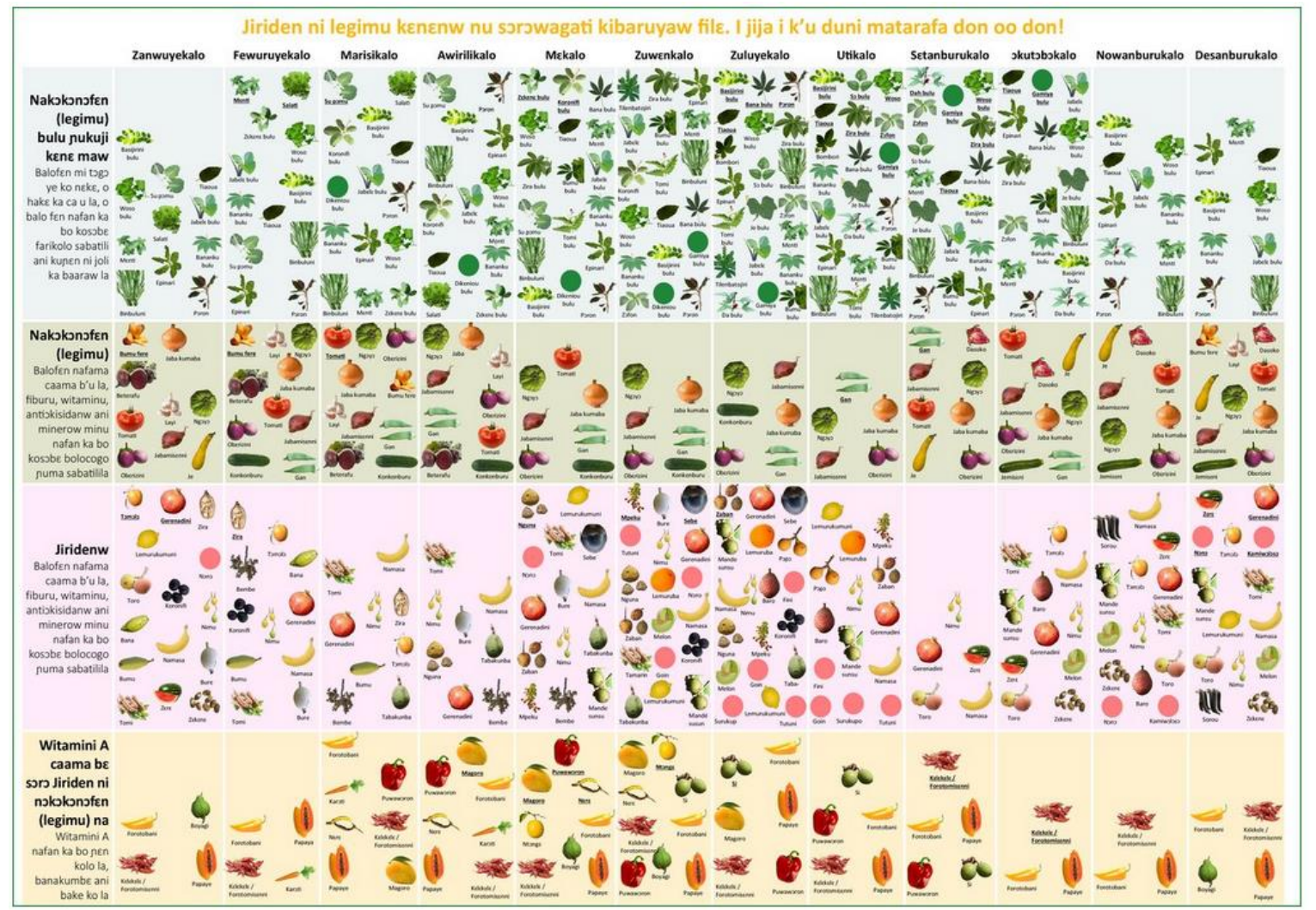

Figure 3. Seasonal calendar of fruits and vegetables in the Segou region, Mali, in the local language. Source: Bioversity International. [41,101].

Table 4. Recipes and novel food products using orphan crops fonio (Digitaria exilis) and Bambara groundnut (Vigna subterranea) in nutrition interventions carried out by Bioversity and the Institut d'Economie Rurale (IER) in Mali.

\begin{tabular}{ll}
\hline \multicolumn{1}{c}{ Fonio } & \multicolumn{1}{c}{ Bambara Groundnut } \\
\hline $\begin{array}{l}\text { Fonio with vegetables } \\
\text { jute mallow leaves }\end{array}$ & $\begin{array}{l}\text { Covafo: a complementary food made with Bambara groundnut, fonio, wheat flour } \\
\text { and dried fruits }\end{array}$ \\
\hline & Tô: Bambara groundnut and fonio flours served with baobab leaf or okra sauce \\
\hline Accra: a paste of soaked and fried Bambara groundnut and spices \\
\hline Shô furu: fried Bambara groundnut flour and baobab leaf powder \\
\hline Fari: steamed Bambara groundnut flour served with vegetables \\
\hline Soup made from de-hulled and smoked grains of Bambara groundnuts \\
\hline Ragoût: made from de-hulled and soaked grains of Bambara groundnuts \\
\hline
\end{tabular}




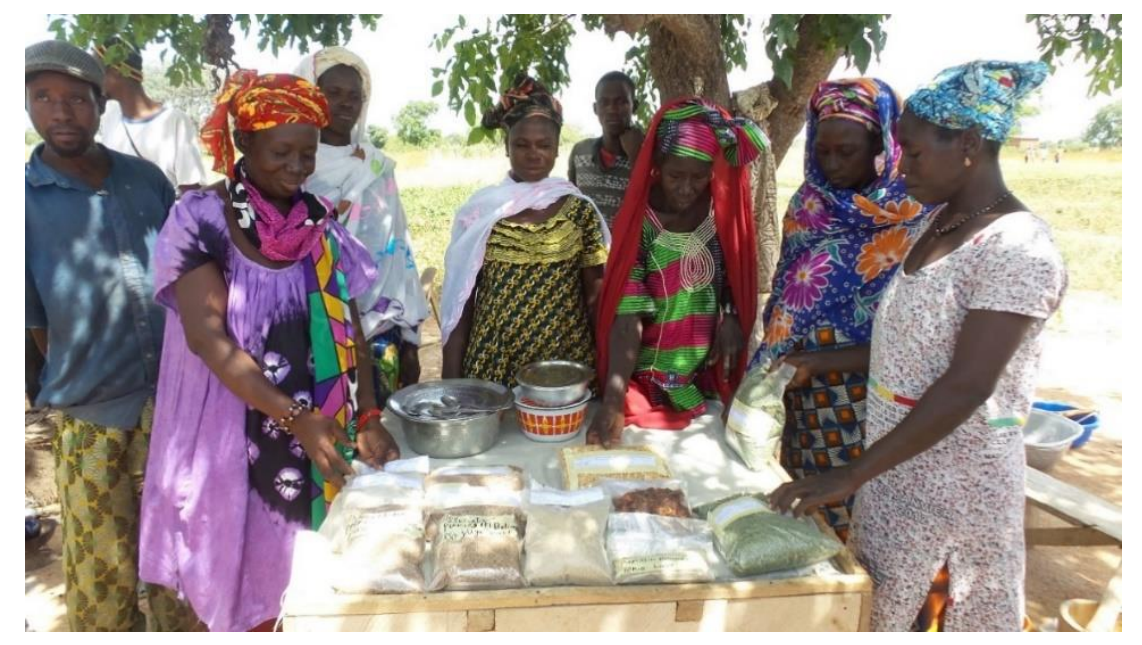

Figure 4. Women with their processed products in Bolimasso, Mali promoting the use and commercialization of fonio and Bambara groundnuts. Credit: Bioversity International/G. Meldrum.

In all countries, engagement with the gastronomy sector and with celebrity chefs has also sparked new interest in these forgotten crops, particularly by urban consumers. In Brazil, the BFN collaboration with federal and state institutions, private sector actors, university professors, researchers and students resulted in the publication of a 900-page recipe book entitled Biodiversidade Brasileira. Sabores e Aromas (Brazilian Biodiversity. Flavors and Aromas) [102], which contains 335 recipes using 64 nutrient-rich underutilized plant species from the six Brazilian regions. This encyclopedic feat represents a huge contribution to the greater promotion of local species and the sustainable use of native biodiversity in general. By the same token, in Guatemala, engagement with Guatemalan chefs Paula Enriquez and Andrei Shrei and a prestigious gastronomy school (Escuela culinaria de alta cocina de Guatemala-ACAM) has led to the inclusion of chaya in the menus of two of the top ten restaurants in Guatemala and direct procurement linkages with the rural women's cooperative (the Integral Marketing Cooperative Chorti-COREDCHORTI) established in the framework of the IFAD-EU-supported project led by Bioversity International (2015-2019) [103].

Special events such as fairs, festivals or national celebrations for World Food Day (Figure 5a-d) that attract wide media coverage can also raise the profile of orphan crops and wild herbs. Notable examples include the Traditional Food Festival in Sri Lanka or the Alaçatı Wild Herb Festival in Turkey, a four-day event devoted entirely to the celebration of wild edibles that promotes the appreciation of local biodiversity-including orphan crops-and attracts tourists, food gourmets, TV food channels and chefs for cooking workshops, food tastings and scientific lectures about the importance of these foods in healthy and sustainable diets.

Much like linking with gastronomy, the festivals, which are becoming increasingly popular, have helped increase the market for orphan crops and wild edibles, an opportunity which has been mostly taken up by women. In Alaçatı, women producers have organized themselves into groups and transformed and sold traditional products/foods made with wild edibles. In Sri Lanka, 20 food outlets by the name of Hela Bojun (literally, True Sri Lankan Taste) sell freshly prepared traditional foods and provide employment to rural women trained by the Women Farmers' Extension Program of the Department of Agriculture on aspects of healthy nutrition, food safety and preparation. By working at the food outlets, women earn between US $\$ 600-\$ 800$ a month, sufficient to enroll their children in school and support the family household [104]. In addition to the above, awareness was also raised among local farmers on the double value of local crops in terms of nutrition and climate change adaptation through community workshops, radio programs and dissemination of dedicated brochures and booklets. These interventions were often carried out in combination with the dissemination to farmers of seeds of the best-performing varieties, which had been jointly evaluated by farmers and agronomists. 


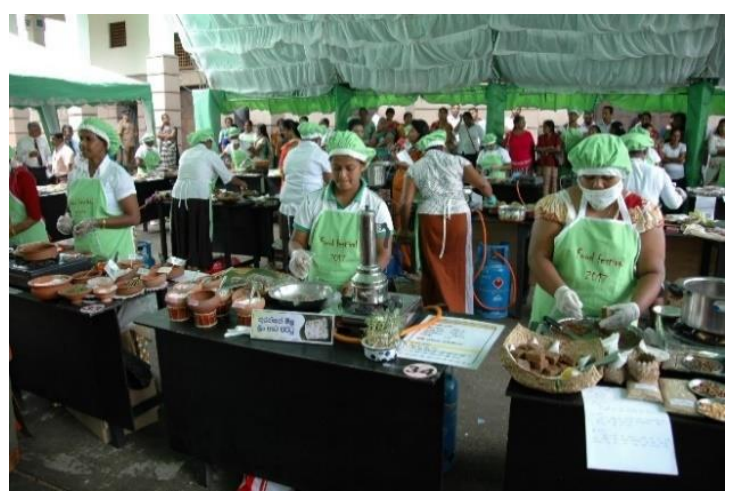

(a)

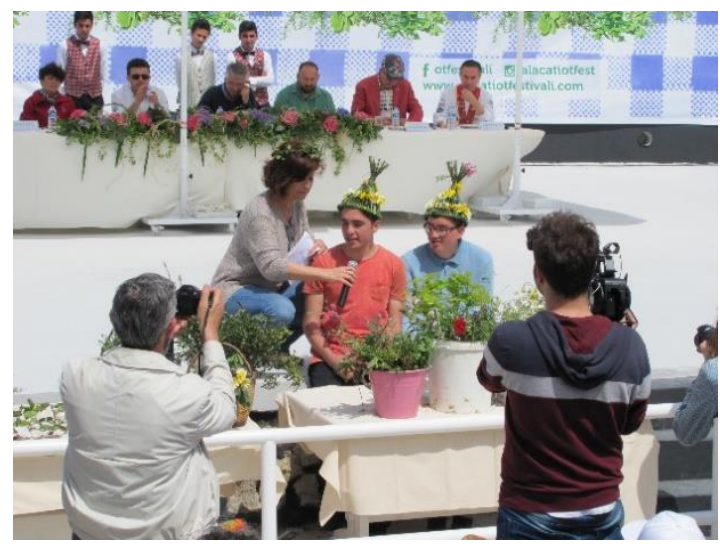

(c)

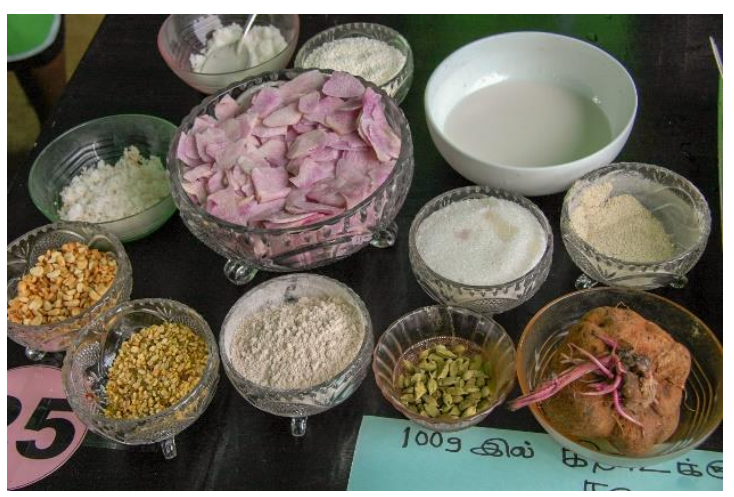

(b)

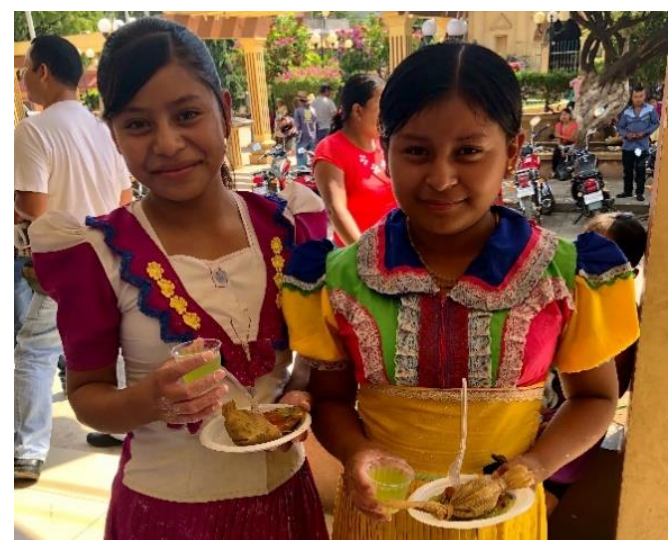

(d)

Figure 5. Festivals and gastronomy events help raise the profile of orphan crops in the intervention countries. (a) Food festival celebrating orphan crops and fruits carried out in Peradeniya, Sri Lanka for World Food Day. Credit: Bioversity International/D. Hunter. (b) Local yam is the main ingredient of a competition recipe at the Food Festival. Credit: Bioversity International/D. Hunter. (c) The young winners of the wild herb collection competition held during the Alaçatı Wild Herb Festival are interviewed by national television. Credit: Bioversity International/D. Hunter. (d) Chaya recipes promoted in Chiquimula Market, Guatemala. Credit: Bioversity International/ N. Amaya.

\section{Conclusions and Recommendations}

Recent global reports and scientific literature on food security and food systems [4,8,94-96], as well as those that are tracking global progress towards the achievement of SDG2 (Zero Hunger), are urging countries to make greater use of locally relevant biodiversity as a means of halting biodiversity loss and making food systems more sustainable. This includes adopting alternative agricultural models that focus on sustainable production and rural development, while empowering consumers to make better decisions around diets that are healthier for people and for the planet [74,105-108]. Thus, actions to achieve SDG2 are likely to fast-track progress towards other goals and targets, including poverty (SDG1); health (SDG3); economic growth (SDG8); sustainable production and consumption (SDG12); climate change (SDG13) and ecosystems, biodiversity and forests (SDG15), among the most relevant. The examples provided have demonstrated that many of these orphan crops and wild edible species provide valuable macro- and micronutrients, as well as beneficial bioactive non-nutrients that contribute to dietary health [26] and could play a key role in addressing local challenges linked to malnutrition, climate change, poverty and shrinking food biodiversity.

The case studies presented have also shown that, with an enabling environment in place, local nutrient-rich crops represent low-hanging fruits for improving dietary diversity and that rapid gains and progress can be made with relatively small effort, time and resources. Furthermore, reinforcing 
the knowledge and use of local plants provides holistic benefits, including strengthening local culinary traditions that are linked to culture and identity, while promoting food and nutrition sovereignty with foods that are available locally and suited to the local climate. Research and development efforts such as those presented in this paper play an important role in filling knowledge gaps and fostering connections between stakeholders in different sectors to promote a greater awareness, production, marketing and integration of orphan crops and wild edible species in public programs, including in sustainable intensification efforts, where orphan crops have been shown to contribute to increasing the output and quality (e.g., nutritional content) of food and other products while using less land, water and other inputs per unit output [4].

In the year 2020, countries will be called upon to critically assess successes and failures in the implementation of the Strategic Plan For Biodiversity (2011-2020) of the Convention on Biological Diversity, to reframe the new global biodiversity framework for the post-2020 era and to endorse the Voluntary Guidelines on Food Systems and Nutrition [23] at the next meeting of the Committee on World Food Security. These two important events represent a unique chance for the orphan crop community to use these tried and tested approaches and visionary thinking developed in these countries to create momentum around the conservation and use of orphan crops and wild edible species for sustainable agriculture, diversified food systems and sustainable and healthy diets.

Although the approach described in this paper is context-specific and likely to change depending on the geography, several broad recommendations are put forward to assist countries and regions wishing to step up efforts to promote the conservation and sustainable consumption of wild edible species and orphan crops. Divided by the three main pillars of the approach, these include:

\subsection{Provide Evidence}

- Encourage and fund research aimed at increasing knowledge and information on the value of orphan crops and wild edibles and of their impact on agriculture-nutrition pathways.

- Step up research investments for domestication programs, particularly of promising wild edible species.

\subsection{Policies and Markets}

- Develop coordinated, multisectoral policies that recognize the importance of orphan crops and wild edible species, and integrate explicit biodiversity for food and nutrition objectives and indicators and concerns in their investment-planning process.

- Develop policies that mainstream the conservation and sustainable use of orphan crops and wild edible species, including strengthening policies that protect unique wild edible collection sites and support ecotourism.

- Support public procurement mechanisms that favor the supply of orphan crops and wild edibles from family farmers/collectors.

- Support the value chain development for new biodiverse products to enhance local businesses and improve farmers' and collectors' livelihoods.

\subsection{Raising Awareness}

- Support nutrition education using culturally and socially appropriate nutrition messaging, which can create a demand for orphan crops and wild species.

- Create awareness campaigns promoting diet diversification and the nutritional, environmental and economic benefits of orphan crops and wild edible species.

Author Contributions: Conceptualization, T.B. and D.H.; investigation, D.M.d.O.B., G.S., V.W.W., G.L., B.G., A.T., Y.K.D. and A.S.; supervision, F.T.; writing—original draft, T.B.; writing—review and editing, D.H., S.P., N.A., G.M., D.M.d.O.B., G.S., V.W.W., G.L., B.G., A.T., Y.K.D., A.S. and F.T. All authors have read and agreed to the published version of the manuscript. 
Funding: Overall support for the Biodiversity for Food and Nutrition (BFN) Project was provided by the Global Environment Facility (GEF Project ID 3808). Co-funding and implementation support were received from the UN Environment Programme; the Food and Agriculture Organization of the United Nations; Bioversity International and the governments of Brazil, Kenya, Sri Lanka and Turkey. Additional funding was received by the Australian Centre for International Agriculture Research for work in Kenya (HORT2014/100, GP2017/007 and GP2018/101), as well as the CGIAR Research Program on Agriculture for Nutrition and Health. For the work in India, Mali and Guatemala, the authors would like to warmly thank the International Fund for Agricultural Development (IFAD) and the European Commission for their support through the Grants 2000000526 and 978, which have contributed to promoting the wider use of neglected and underutilized species to improve the livelihood of people, especially the poor and vulnerable.

Acknowledgments: The authors would also like to gratefully acknowledge the many colleagues and institutions in participating countries that contributed to the work described in this paper. The activities and outcomes of the BFN Project contributes to the implementation of the Convention on Biological Diversity's Cross-Cutting Initiative on Biodiversity for Food and Nutrition.

Conflicts of Interest: The authors declare no conflicts of interest, and the funders had no role in the design of the study; in the collection, analyses or interpretation of data; in the writing of the manuscript or in the decision to publish the results.

\section{References}

1. FAO. World Food and Agriculture—Statistical Pocketbook 2018; Food and Agriculture Organization of the United Nations: Rome, Italy, 2018; 254p.

2. FAO; IFAD; UNICEF; WFP; WHO. The State of Food Security and Nutrition in the World 2018. Building Climate Resilience for Food Security and Nutrition; FAO: Rome, Italy, 2018.

3. Khoury, C.K.; Bjorkmanc, A.D.; Dempewolf, H.; Ramirez-Villegasa, J.; Guarino, L.; Jarvis, A.; Riesebergd, L.H.; Struik, P.C. Increasing homogeneity in global food supplies and the implications for food security. Proc. Natl. Acad. Sci. USA 2014, 111, 4001-4006. [CrossRef] [PubMed]

4. FAO. The State of the World's Biodiversity for Food and Agriculture, 1st ed.; Bélanger, J., Pilling, D., Eds.; FAO Commission on Genetic Resources for Food and Agriculture Assessments: Rome, Italy, 2019; 572p.

5. Kc, K.B.; Dias, G.M.; Veeramani, A.; Swanton, C.J.; Fraser, D.; Steinke, D.; Lee, E.; Wittman, H.; Farber, J.M.; Dunfield, K.; et al. When too much isn't enough: Does current food production meet global nutritional needs? PLOS ONE 2018, 13, e0205683.

6. Siegel, K.R.; Ali, M.K.; Srinivasiah, A.; Nugent, R.A.; Venkat Narayan, K.M. Do we produce enough fruits and vegetables to meet global health need? PLOS ONE 2014, 9, e104059.

7. Padulosi, S.; Sthapit, B.; Lamers, H.; Kennedy, G.; Hunter, D. Horticultural biodiversity to attain sustainable food and nutrition security. Acta Hortic. 2018, 1205, 21-34. [CrossRef]

8. Repeated 86 Willett, W.; Rockström, J.; Loken, B.; Springmann, M.; Lang, T.; Vermeulen, S.; Garnett, T.; Tilman, D.; DeClerck, F.; Wood, A.; et al. Food in the Anthropocene: The EAT-Lancet Commission on healthy diets from sustainable food systems. Lancet 2019, 393, 447-492.

9. IPBES. Summary for policymakers of the global assessment report on biodiversity and ecosystem services of the Intergovernmental Science-Policy Platform on Biodiversity and Ecosystem Services; Díaz, S., Settele, J., Brondizio, E.S., Ngo, H.T., Guèze, M., Agard, J., Arneth, A., Balvanera, P., Brauman, K.A., Butchart, S.H.M., et al., Eds.; IPBES Secretariat: Bonn, Germany, 2019.

10. UN Environment. Global Environment Outlook—GEO-6: Healthy Planet, Healthy People; Cambridge University Press: Cambridge, UK, 2019; 745p. [CrossRef]

11. Gruberg, H.; Meldrum, G.; Padulosi, S.; Rojas, W.; Pinto, M.; Crane, T. Towards a Better Understanding of Custodian Farmers and Their Roles: Insights from a Case Study in Cachilaya, Bolivia; Bioversity International, Rome and Fundación PROINPA: La Paz, Bolivia, 2013; 33p.

12. Sthapit, B.; Lamers, H.; Rao, R. (Eds.) Custodian Farmers of Agricultural Biodiversity: Selected Profiles from South and South East Asia; Bioversity International: Rome, Italy, 2013.

13. Sthapit, S.; Meldrum, G.; Padulosi, S.; Bergamini, N. (Eds.) Strengthening the role of custodian farmers in the national conservation programme of Nepal. In Proceedings of the National Workshop, Pokhara, Nepal, 31 July2 August 2013; Bioversity International: Rome, Italy; LI-BIRD: Pokhara, Nepal, 2015.

14. Bioversity International. Mainstreaming Agrobiodiversity in Sustainable Food Systems: Scientific Foundations for an Agrobiodiversity Index; Bioversity International: Rome, Italy, 2017. 
15. Egeland, G.M.; Harrison, G. Health disparities: Promoting indigenous peoples' health through traditional food systems and self-determination. In Indigenous Peoples' Food Systems and Well-Being; Kuhnlein, H.V., Erasmus, B., Spigelski, D., Burlingame, B., Eds.; FAO: Rome, Italy, 2013.

16. Turner, N.J.; Plotkin, M.; Kuhnlein, H.V. Global environmental challenges to the integrity of indigenous peoples' food systems. In Indigenous Peoples' Food Systems and Well-Being; Kuhnlein, H.V., Erasmus, B., Spigelski, D., Burlingame, B., Eds.; FAO: Rome, Italy, 2013.

17. United Nations. Transforming our world: The 2030 Agenda for Sustainable Development; 2015 A/RES/70/1; United Nations: San Francisco, CA, USA, 2015.

18. FAO and WHO. Rome Declaration on Nutrition; ICN2 2014/2; FAO: Rome, Italy, 2014.

19. FAO. Framework for Action. ICN2 2014/3 Corr.1. In Proceedings of the Conference Outcome Document from the Second International Conference on Nutrition, Rome, Italy, 19-21 November 2014. Available online: http://www.fao.org/3/a-mm215e.pdf (accessed on 3 February 2020).

20. United Nations. General Assembly (UNGA) Resolutions 70/259 and 72/306. Available online: https: //undocs.org/en/A/RES/70/259 (accessed on 3 February 2020).

21. United Nations. General Assembly (UNGA). Resolution A/RES/73/2. Political Declaration of the Third High-Level Meeting of the General Assembly on the Prevention and Control of Non-Communicable Diseases. Available online: https://undocs.org/en/A/RES/73/2 (accessed on 3 February 2020).

22. WHO. Global Action Plan for the Prevention and Control of Noncommunicable Diseases 2013-2020. 2013. Available online: https://apps.who.int/iris/bitstream/handle/10665/94384/9789241506236_eng.pdf?sequence= 1 (accessed on 3 February 2020).

23. CFS (Committee on World Food Security). Zero Draft Voluntary Guidelines on Food Systems and Nutrition. 2020. Available online: http://www.fao.org/fileadmin/templates/cfs/Docs1819/Nutrition/CFS_Zero_Draft_ Voluntary_Guidelines_Food_Systems_and_Nutrition.pd (accessed on 3 February 2020).

24. United Nations. General Assembly (UNGA). A/RES/73/132. Global Health and Foreign Policy: A Healthier World through Better Nutrition. Available online: https:/undocs.org/en/A/RES/73/132 (accessed on 3 February 2020).

25. United Nations. General Assembly (UNGA). A/RES/73/253 Agriculture Development, Food Security and Nutrition. Available online: https://undocs.org/en/A/RES/73/253 (accessed on 3 February 2020).

26. HLPE. Agroecological and other innovative approaches for sustainable agriculture and food systems that enhance food security and nutrition. In A Report by the High-Level Panel of Experts on Food Security and Nutrition of the Committee on World Food Security; HLPE: Rome, Italy, 2019.

27. Padulosi, S.; Roy, P.; Rosado-May, F.J. Supporting Nutrition Sensitive Agriculture through Neglected and Underutilized Species_Operational Framework; Bioversity International and IFAD: Rome, Italy, 2019; 39p, Available online: https://cgspace.cgiar.org/handle/10568/102462 (accessed on 3 February 2020).

28. Hunter, D.; Borelli, T.; Beltrame, D.M.O.; Oliveira, C.N.S.; Coradin, L.; Wasike, V.W.; Wasilwa, L.; Mwai, J.; Manjella, A.; Samarasinghe, G.W.L.; et al. Potential of orphan crops for improving diets and nutrition. Special Issue on Orphan Crops: Contributions to Current and Future Agriculture. Planta 2019. [CrossRef]

29. Hunter, D.; Borelli, T.; Olsen Lauridsen, N.; Gee, E.; Rota Nodari, G.; Moura de Oliveira Beltrame, D.; Oliveira, C.; Wasike, V.W.; Samarasinghe, G.; Tan, A.; et al. Biodiversity Mainstreaming for Healthy \& Sustainable Food Systems: A Toolkit to Support Incorporating Biodiversity into Policies and Programmes; Bioversity International: Rome, Italy, 2018; 52p.

30. Gee, E.; Borelli, T.; Beltrame, D.M.O.; Oliveira, C.N.S.; Coradin, L.; Wasike, V.; Manjella, A.; Samarasinghe, G.; Güner, B.; Tan, A.; et al. The ABC of mainstreaming biodiversity for food and nutrition: Concepts, theory and practice. In Biodiversity, Food and Nutrition. A New Agenda for Sustainable Food Systems; Hunter, D., Borelli, T., Gee, E., Eds.; Routledge: London, UK. (In Press)

31. CBD. National Biodiversity Index of the Convention on Biological Diversity. Extracted from the Global Biodiversity Outlook 1. Annex 1. Biodiversity Information by Country. Available online: https://www.cbd. int/gbo1/annex.shtml\#note1 (accessed on 3 February 2020).

32. Convention on Biological Diversity. Brazil_Country Profile; Biodiversity Facts: Montreal, Canada, 2016. Available online: https://www.cbd.int/countries/profile/?country=br (accessed on 4 February 2020).

33. Global Nutrition Report. Country Nutrition Profiles. Available online: https://globalnutritionreport.org/ resources/nutrition-profiles/ (accessed on 3 February 2020). 
34. Padulosi, S.; Bhag Mal, O.; King, I.; Gotor, E. Minor Millets as a Central Element for Sustainably Enhanced Incomes, Empowerment, and Nutrition in Rural India. Sustainability 2015, 7, 8904-8933. [CrossRef]

35. Raneri, J.E.; Padulosi, S.; Meldrum, J.; King, O.I. Promoting neglected and underutilized species to boost nutrition in LMICs. In UNSCN Nutrition 44-Food Environments: Where People Meet the Food System; UNSCN: Rome, Italy, 2019; pp. 10-25. Available online: https:/www.unscn.org/uploads/web/news/UNSCNNutrition44-WEB-version.pdf (accessed on 3 February 2020).

36. Mittermeier, R.A.; Gil, P.R.; Mittermeier, C.G. Megadiversity: Earth's Biologically Wealthiest Nations; Conservation International: Washington, DC, USA, 1997.

37. Development Initiatives. Brazil country nutrition profile. In 2018 Global Nutrition Report: Shining a Light to Spur Action on Nutrition; Development Initiatives: Bristol, UK, 2018.

38. Von Grebmer, K.; Bernstein, J.; Patterson, F.; Wiemers, M.; Chéilleachair, R.N.; Foley, C.; Gitter, S.; Ekstrom, K.; Fritschel, H. 2019 Global Hunger Index. Climate Justice: A New Narrative for Action Concern Worldwide and Welthungerhilfe; Helvetas: Zürich, Switzerland, 2019.

39. Development Initiatives. Mali country nutrition profile. In 2018 Global Nutrition Report: Shining a Light to Spur Action on Nutrition; Development Initiatives: Bristol, UK, 2018.

40. Nordeide, M.B.; Hatløy, A.; Følling, M.; Lied, E.; Oshaug, A. Nutrient composition and nutritional importance of green leaves and wild food resources in an agricultural district, Koutiala, in Southern Mali. Int. J. Food Sci. Nutr. 1996, 47, 455-468. [CrossRef]

41. Bioversity International and Institut d'Economie Rurale. Calendrier saisonnier des fruits et légumes pour une alimentation diversifiée dans la région de Sikasso; Bioversity International and Institut d'Economie Rurale: Mali, Rome, Italy, 2018.

42. De la Peña, I.; Garrett, J.; Gelli, A. Nutrition-Sensitive Value Chains from a Smallholder Perspective. A Framework for Project Design; IFAD Research Series: Rome, Italy, 2018.

43. Diawara, F. Characterization of Food Consumption Patterns in Southern Mali: Districts of Bougouni and Koutiala Sikasso; IITA: Ibadan, Nigeria, 2013.

44. Kobori, N.C.; Rodriguez-Amaya, D.B. Uncultivated Brazilian green leaves are richer sources of carotenoids than are commercially produced leafy vegetables. Food Nutr. Bull. 2008, 29, 320-328. [CrossRef]

45. Bharucha, Z.; Pretty, J. The roles and values of wild foods in agricultural systems. Philos. Trans. R. Soc. B 2010, 365, 2913-2926. [CrossRef]

46. Padulosi, S.; Hunter, D.; Jarvis, A.; Heywood, V. Underutilized crops and climate change - current status and outlook. In Crop Adaptation to Climate Change; Yadav, S., Redden, B., Hatfield, J.L., Lotze-Campen, H., Eds.; Wiley-Blackwell: Ames, IA, USA, 2011; pp. 507-521.

47. Kahane, R.; Hodgkin, T.; Jaenicke, H.; Hoogendoorn, C.; Hermann, M.; Keatinge, J.D.H.; d'Arros Hughes, J.; Padulosi, S.; Looney, N. Agrobiodiversity for food security, health and income. Agron. Sustain. Dev. 2013, 33, 671-693. [CrossRef]

48. Padulosi, S.; Thompson, J.; Rudebjer, P. Fighting Poverty, Hunger and Malnutrition with Neglected and Underutilized Species (NUS): Needs, Challenges and the Way Forward; Bioversity International: Rome, Italy, 2013; 56p, ISBN 978-92-9043-941-7.

49. Hunter, D.; Özkan, I.; Beltrame, D.; Samarasinghe, W.L.G.; Wasike, V.W.; Charrondière, U.R.; Borelli, T.; Sokolow, J. Enabled or disabled: Is the environment right for using biodiversity to improve nutrition? Front. Nutr. 2016, 3, 14. [CrossRef] [PubMed]

50. Da Silva, J.G.; Del Grossi, M.E.; de França, C.G. (Eds.) The Fome Zero (Zero Hunger) Program: The Brazilian Experience; MDA: Brasília, Brazil, 2010. Available online: http://www.fao.org/3/a-i3023e.pdf (accessed on 28 January 2020).

51. UNSCN Discussion Paper. Schools as a System to Improve Nutrition: A New Statement for School-Based Food and Nutrition Interventions; United Nations System Standing Committee on Nutrition: Rome, Italy, 2017. Available online: https://www.unscn.org/uploads/web/news/document/School-Paper-EN-WEB.pdf (accessed on 30 October 2019).

52. Biodiversity for Food and Nutrition Project (BFN Project). Homepage. Available online: www.b4fn.org (accessed on 3 February 2020). 
53. Government of the Republic of Kenya. Busia County Biodiversity Policy. 2016-2023; Busia County Government: Busia, Kenya, 2016. Available online: http://www.b4fn.org/fileadmin/templates/b4fn.org/upload/documents/ Country_additional_resources/Kenya/Busia_County_Biodiversity_Policy_10_Oct_2017_Final.pdf (accessed on 3 February 2020).

54. Bioversity International and Universidad del Valle de Guatemala. Calendario Estacional de Frutas y Vegetales para la Diversidad Dietética Jocotán y Camotán, Chiquimula, Guatemala; Bioversity International and Universidad del Valle de Guatemala: Rome, Italy, 2018.

55. Greenfield, H.; Southgate, D.A.T. Food Composition Data; Production Management and Use, Food and Agriculture Organization of the United Nations: Rome, Italy, 2003.

56. FAO/INFOODS Food Composition Database for Biodiversity. Available online: http://www.fao.org/infoods/ infoods/food-biodiversity/en/ (accessed on 3 February 2020).

57. FAO. Voluntary Guidelines for Mainstreaming Biodiversity into Policies, Programmes and National and Regional Plans of Action on Nutrition; FAO: Rome, Italy, 2016. Available online: http://www.fao.org/3/a-i5248e.pdf (accessed on 27 January 2020).

58. Haddad, L.; Isenman, P. Which aid spending categories have the greatest untapped potential to support the reduction of undernutrition? Some ideas on moving forward. Food Nutr. Bull. 2014, 35, 266-276. [CrossRef] [PubMed]

59. System on Brazilian Biodiversity (SiBBr) Database. Available online: https://ferramentas.sibbr.gov.br/ficha/ bin/view/FN/? \&firstIndex=180 (accessed on 3 February 2020).

60. Charrondière, U.R. Personal Communication; Food and Agriculture Organization of the United Nations: Rome, Italy, 2018.

61. Tabela Brasileira de Composição de Alimentos-TBCA; Versão 7.0.; Universidade de São Paulo (USP); Food Research Center (FoRC): São Paulo, Brazil, 2019. Available online: http://www.fcf.usp.br/tbca (accessed on 30 October 2019).

62. Burlingame, B.; Charrondière, U.R.; Mouille, B. Food composition is fundamental to the cross-cutting initiative on biodiversity for food and nutrition. J. Food Compos. Anal. 2009, 22, 361-365. [CrossRef]

63. Biodiversity for Food and Nutrition (BFN) Species Database. Available online: http://www.b4fn.org/ resources/species-database/ (accessed on 3 February 2020).

64. FAO/INFOODS. Food Composition Database for Biodiversity (BioFoodComp 2.1). 2013. Available online: http://www.fao.org/docrep/019/i3560e/i3560e.pdf (accessed on 30 October 2019).

65. Lachat, C.; Raneri, J.E.; Walker Smith, K.; Kolsteren, P.; Van Damme, P.; Verzelen, K.; Penafiel, D.; Vanhove, W.; Kennedy, G.; Hunter, D.; et al. Dietary species richness as a measure of food biodiversity and nutritional quality of diets. Proc. Natl. Acad. Sci. USA 2018, 115, 127-132. [CrossRef]

66. Ross-Ibarra, J.; Molina-Cruz, A. The ethnobotany of chaya (Cnidoscolus aconitifolius ssp. aconitifolius Breckon): A nutritious maya vegetable. Econ. Bot. 2002, 56, 350-365. [CrossRef]

67. Molina-Cruz, A.; Curley, L.; Bressani, R. Redescubriendo el valor nutritivo de las hojas de chaya (Cnidoscolus aconitifolius; Euphorbiaceae). Univ. Valle Guatem. 1997, 3, 1-4.

68. Small, E. Teff \& fonio-Africa's sustainable cereals. Biodiversity 2015, 16, 37-41.

69. Mubaiwa, J.; Fogliano, V.; Chidewe, C.; Linnemann, A.R. Hard-to-cook phenomenon in Bambara groundnut (Vigna subterranea (L.) Verdc.) processing: Options to improve its role in providing food security. Food Rev. Int. 2017, 33, 167-194. [CrossRef]

70. FAO/Government of Kenya. Kenya Food Composition Tables; FAO/Government of Kenya: Nairobi, Kenya, 2018; p. 254. Available online: http://www.fao.org/3/I9120EN/i9120en.pdf (accessed on 30 October 2019).

71. Vall, E.; Andrieu, N.; Beavogui, F.; Sogodogo, D. Les cultures de soudure comme stratégie de lutte contre l'insécurité alimentaire saisonnière en Afrique de l'Ouest: Le cas du fonio (Digitaria exilis Stapf). Cahiers Agricoles 2011, 20, 94-300.

72. Dewbre, J.; Borot de Battisti, A. Agricultural Progress in Cameroon, Ghana and Mali: Why It Happened and How to Sustain It. In OECD Food, Agriculture and Fisheries Working Papers, No. 9; OECD Publishing: Paris, France, 2008. [CrossRef]

73. Cruz, J.; Béavogui, F. Fonio, an African Cereal; Editions CIRAD: Montpellier, France, 2016; 153p, ISBN 978-2-87614-720-1.

74. Cooper, M.W.; West, C.T. Unravelling the Sikasso paradox: Agricultural change and malnutrition in Sikasso, Mali. Ecol. Food Nutr. 2017, 56, 101-123. [CrossRef] [PubMed] 
75. Amaya, N.; Padulosi, S.; Meldrum, G. Value Chain Analysis of Chaya (Mayan Spinach) in Guatemala. Econ. Bot. 2019, 1-15. [CrossRef]

76. CBD. Strategic Plan for Biodiversity 2011-2020 and the Aichi Targets. "Living in Harmony with Nature". 2011. Available online: https://www.cbd.int/doc/strategic-plan/2011-2020/Aichi-Targets-EN.pdf (accessed on 3 February 2020).

77. IPES-Food. From Uniformity to Diversity: A Paradigm Shift from Industrial Agriculture to Diversified Agroecological Systems; International Panel of Experts on Sustainable Food systems: Brussels, Belgium, 2016. Available online: http://www.ipes-food.org/_img/upload/files/UniformityToDiversity_FULL.pdf (accessed on 30 October 2019).

78. FOLU. Growing Better: Ten Critical Transitions to Transform. Food and Land Use. The Global Consultation Report of the Food and Land Use Coalition; The Food and Land Use Coalition: London, UK, 2019. Available online: https://www. foodandlandusecoalition.org/wp-content/uploads/2019/09/FOLU-GrowingBetter-GlobalReport.pdf (accessed on 30 October 2019).

79. WHO/CBD, World Health Organization and Secretariat of the Convention on Biological Diversity. Connecting Global Priorities: Biodiversity and Human Health. A State of Knowledge Review; WHO Press: Geneva, Switzerland, 2015. Available online: https://www.cbd.int/health/SOK-biodiversity-en.pdf (accessed on 30 October 2019).

80. MoMD\&E, Ministry of Mahaweli Development and Environment. National Biodiversity Strategic Action Plan. 2016-2022; Biodiversity Secretariat, Ministry of Mahaweli Development and Environment: Colombo, Sri Lanka, 2016. Available online: https://www.cbd.int/doc/world/lk/lk-nbsap-v2-en.pdf (accessed on 30 October 2019).

81. MoE, Ministry of Environment. National Biodiversity Strategy and Action Plan; Ministry of Environment-MMA, Biodiversity Secretariat: Brasília, Brazil, 2017. Available online: https://www.cbd.int/doc/world/br/br-nbsapv3-en.pdf (accessed on 30 October 2019).

82. MoE \& MoSD, Ministry of Environment and Ministry of Social Development. Diário oficial da união. Portaria Interministerial $N^{o} 284$ de 30 de Maio de 2018, 131, 92, Imprensa Nacional, Brazil. Available online: https://ciorganicos.com.br/wp-content/uploads/2018/07/PORTARIA-INTERMINISTERIAL-N\%C2\% BA-284.pdf (accessed on 30 October 2019).

83. Beltrame, D.M.; Oliveira, C.N.S.; Borelli, T.; de Santiago, A.C.; Monego, E.T.; Vera de Rosso, V.; Coradin, L.; Hunter, D. Diversifying institutional food procurement-Opportunities and barriers for integrating biodiversity for food and nutrition in Brazil. Revista Raizes 2016, 36, 55-69.

84. Santana, C.A.M.; Nascimento, J.R. Public Policies and Agricultural Investment in Brazil; Food and Agriculture Organization of the United Nations. Policy Assistance Support Service (TCSP): Brasília, Brazil, 2012.

85. MoAPA, Ministério da Agricultura, Pecuária e Abastecimento. Diário Oficial da União. Portaria $n^{\circ} 141$, de 8 de Janeiro de 2019, 7, 12, Gabinete do Ministro: Brasilia, Brazil. Available online: http://pesquisa.in.gov.br/ imprensa/jsp/visualiza/index.jsp?data=10/01/2019\&jornal=515\&pagina=12 (accessed on 3 February 2020).

86. Valencia, V.; Wittman, H.; Blesh, J. Structuring Markets for Resilient Farming Systems. Agron. Sustain. Dev. 2019, 39, 25. [CrossRef]

87. Béné, C.; Prager, S.; Achicanoy, H.; Toro, P.; Lamotte, L.; Cedrez, C.; Mapes, B. Understanding food systems drivers: A critical review of the literature. Glob. Food Secur. 2019, 23, 149-159. [CrossRef]

88. FAO. Sustainable Value Chains for Sustainable Food Systems: A Workshop of the FAO/UNEP Programme on Sustainable Food Systems; FAO: Rome, Italy, 2016.

89. IFAD NUS Project. Homepage. Available online: http://www.nuscommunity.org (accessed on 3 February 2020).

90. Tartanac, F.; Swensson, L.F.J.; Polo Galante, A.; Hunter, D. Institutional food procurement for promoting sustainable diets. In Sustainable Diets: The Transdisciplinary Imperative; Burlingame, B., Dernini, S., Eds.; CABI: Wallingford, UK, 2018.

91. Mabhaudhi, T.; Chibarabada, T.P.; Chimonyo, V.G.P.; Murugani, V.G.; Pereira, L.M.; Sobratee, N.; Govender, L.; Slotow, R.; Modi, A.T. Mainstreaming Underutilized Indigenous and Traditional Crops into Food Systems: A South African Perspective. Sustainability 2019, 11, 172. [CrossRef]

92. Padulosi, S.; Bala Ravi, S.; Rojas, W.; Valdivia, R.; Jager, M.; Polar, V.; Gotor, E.; Mal, B. Experiences and lessons learned in the framework of a global UN effort in support of neglected and underutilized species. ISHS Acta Hortic. 2013, 979, 517-531. [CrossRef]

93. The Gazette of India. National Food Security Act. 10 September 2013. Available online: http://egazette.nic. in/WriteReadData/2013/E_29_2013_429.pdf (accessed on 30 October 2019). 
94. Padulosi, S.; Mal, B.; Ravi, S.B.; Gowda, J.; Gowda, K.T.K.; Shanthakumar, G.; Yenagi, N.; Dutta, M. Food security and climate change: Role of plant genetic resources of minor millets. Indian J. Plant Genet. Resour. 2009, 22, 1-16.

95. King, O.I.; Padulosi, S. Agricultural biodiversity and women's empowerment: A successful story from Kolli Hills, India. In Creating Mutual Benefits: Examples of Gender and Biodiversity Outcomes from Bioversity International's Research; Del Castello, A., Bailey, A., Eds.; Bioversity International: Rome, Italy, 2017; $4 \mathrm{p}$, Available online: https://www.bioversityinternational.org/fileadmin/user_upload/Creating_GSICP.pdf (accessed on 30 October 2019).

96. Caron, P.; de Loma-Osorio, G.F.; Nabarro, D.; Hainzelin, E.; Guillou, M.; Andersen, I.; Arnold, T.; Astralaga, M.; Beukeboom, M.; Bickersteth, S.; et al. Food systems for sustainable development: Proposals for a four-part transformation. Agron. Sustain. Dev. 2018, 38, 41. [CrossRef] [PubMed]

97. Grasso, A. School Gardening in Busia County, Kenya. A case study. BFN Project website. 2015. Available online: http://www.b4fn.org/from-the-field/stories/school-gardening-in-busia-county-kenya (accessed on 3 February 2020).

98. Tan, A.; Adanacioğlu, N.; Tuğrul Ay, S. Students in Nature, in the Garden and in the Kitchen, Turkey. A case Study. BFN Project Website. 2018. Available online: http://www.b4fn.org/case-studies/case-studies/studentsin-nature-in-the-garden-and-in-the-kitchen (accessed on 3 February 2020).

99. Searchinger, T.; Waite, R.; Hanson, C.; Ranganathan, J.; Matthews, E. World Resources Report Creating a Sustainable Food Future: A Menu of Solutions to Feed Nearly 10 Billion People by 2050; Worlds Resources Institute: Washington, DC, USA, 2019.

100. Hawkes, C.; Blouin, C.; Henson, S.; Drager, N.; Dubé, L. Trade, Food, Diet. and Health. Perspectives and Policy Options; Wiley-Blackwell: Hoboken, NJ, USA, 2009.

101. Lochetti, G.; Robitaille, R. Adding colour to rural diets year-round with the Seasonal Food Availability Booklet. 2018. Available online: https:/www.bioversityinternational.org/news/detail/adding-colour-torural-diets-year-round-with-the-seasonal-food-availability-booklet (accessed on 3 February 2020).

102. MoH, Ministry of Health. Dietary Guidelines for the Brazilian Population; Ministry of Health: Brasilia, Brazil, 2015. Available online: http://bvsms.saude.gov.br/bvs/publicacoes/dietary_guidelines_brazilian_population.pdf (accessed on 30 October 2019).

103. IFAD NUS Project. About the project. Available online: http://www.nuscommunity.org/initiatives/ifad-euccafs-nus/ (accessed on 3 February 2020).

104. FAO and FHI 360. Minimum Dietary Diversity for Women: A Guide for Measurement; FAO: Rome, Italy, 2016.

105. De Andrade Cardoso Santiago, R.; Coradin, L. (Eds.) Biodiversidade Brasileira: Sabores e aromas; Ministério do Meio Ambiente: Brasília, Brazil, 2019. Available online: http://redesans.com.br/rede/wp-content/uploads/ 2019/08/Livro-de-Receitas-03-07-2019.pdf (accessed on 30 October 2019).

106. Rathnasinghe, D.; Samarasinghe, G.; Silva, R.; Hunter, D. ‘True Sri Lanka Taste' food outlets: Promoting indigenous foods for healthier diets. Nutr. Exch. 2019, 12, 14-15.

107. HLPE. Nutrition and food systems. In A Report by the High Level Panel of Experts on Food Security and Nutrition of the Committee on World Food Security; HLPE Report 12; FAO: Rome, Italy, 2017. Available online: http://www.fao.org/3/a-i7846e.pdf (accessed on 30 October 2019).

108. Vermeulen, S.; Park, T.; Khoury, C.K.; Mockshell, J.; Béné, C.; Thi, H.T.; Heard, B.; Wilson, B. Changing Diets and Transforming Food Systems; CCAFS Working Paper no. 282; CGIAR Research Program on Climate Change, Agriculture and Food Security (CCAFS): Wageningen, The Netherlands, 2019. Available online: https:/cgspace.cgiar.org/bitstream/handle/10568/103987/Changing\%20diets\%20and\%20transforming\% 20food\%20systems\%20WP\%20282_repaired.pdf (accessed on 30 October 2019).

(C) 2020 by the authors. Licensee MDPI, Basel, Switzerland. This article is an open access article distributed under the terms and conditions of the Creative Commons Attribution (CC BY) license (http://creativecommons.org/licenses/by/4.0/). 